\title{
Human health risk assessment of temporal and spatial variations of ground water quality at a densely industrialized commercial complex at Haridwar, India
}

\section{Tushar Arora ${ }^{*}$, Anand Mishra, Gagan Matta, A. K. Chopra, Ajendra Kumar ${ }^{1}$, D. R. Khanna and Vinod Kumar}

Department of Zoology and Environmental Science, Gurukula Kangri University, Haridwar-249404 (Uttarakhand), INDIA

${ }^{1}$ Department of Mathematics and Statistics, Gurukula Kangri University, Haridwar-249404 (Uttarakhand), INDIA

*Corresponding author. E-mail: tushararora09@ rediffmail.com

Received: July 05, 2014 Revised received: October 05, 2014 Accepted: December 16, 2014

Abstract: The observations of present investigation revealed that the groundwater regime at State Infrastructure and Industrial Development Corporation of Uttarakhand Limited (SIDCUL) Industrial Estate (IE) was highly responsive to the anthropogenic stress of recharge and discharge parameters concerning the distressing industrial activities. The present study on groundwater characteristics of SIDCUL-IE, Haridwar in year 2013-2014 showed that the water of Sampling station-D (SSD) had relatively poor quality in comparison to the groundwater collected from Sampling station-A (SSA), Sampling station-B (SSB) and Sampling station-C (SSC). The samples had a high mineral load with relatively wider $\mathrm{pH}$ range. The physico-chemical parameters like $\mathrm{pH}$ (6.35 in October) at SSA, TDS (553.5 mg/l in November) at SSC, TH (600.0 mg/l in July) at SSB and alkalinity (525.0 mg/l in October) at SSD were beyond the prescribed limits of Bureau of Indian Standards (BIS). The Karl Pearson correlation matrix showed moderate to significantly positive correlation between various parameters like COD-phosphorus $(r=0.629)$, temperature-DO $(r=-0.477)$ at SSA; $\mathrm{pH}$ and bicarbonate $(r=0.668)$ at SSB; $\mathrm{pH}$-temperature $(r=-0.551)$,turbidity-BOD $(r=0.467)$, BOD-phosphorus ( $r=0.518)$, bicarbonate-acidity $(r=-0.833)$ at SSC and TSS-turbidity $(r=0.616)$, BOD-COD $(r=0.6771)$ at SSD and temperature-DO $(r=-0.666)$, hardness-acidity $(r=-0.6542)$ BOD-COD $(r=0.654)$ at control site. The overall quality of groundwater, though hard, was found acceptable for drinking purpose. The divergence in the results of groundwater samples taken from SIDCUL-IE and the Control site, $2 \mathrm{~km}$ away from SIDCUL-IE, indicated that groundwater pollution is increasing alarmingly which may have serious threats to human health in near future.

Keywords: Groundwater quality, Human health-risk, Industrial effluents, Physico-chemical parameters, SIDCUL, Spatial, Temporal.

\section{INTRODUCTION}

The significance of pure drinking water is much understood and needs least to be explained. Pure water is a limited, precious and renewable natural resource which cannot be produced synthetically. Rapid increase in population has exerted a continuous thrust on this limited natural resource (Watson and Davies 2009). Simultaneously, the constantly increasing industrialization and ever expanding urbanization have considerably increased the rate of groundwater pollution. The pollution of groundwater resource due to devastating industrial activities has threatened the existence of human beings including other organisms that rely on freshwater resources for their survival. The crises are more severe in developing countries like India, having higher rate of increase in population and industrialization (Subbarao et al., 1998 and Rao et al., 2001). Underground water resource, which is the major drinking water source in India, is frequently being contaminated by the discharge of poor quality effluents from the industrial establishments (Singh 2001; Pujari and Deshpande 2005; Mondal et al., 2005; Singh et al., 2006; Naik et al., 2007; Ullah et al., 2009; Aulakh et al., 2009; Patel et al., 2010; Nubi and Ajuonu 2011; Brindha and Elango 2012; Bhadra et al., 2013; Bingbing et al., 2014 and Brindha et al., 2014). The aquatic systems in the close proximity of industries serve as the principal means for the disposal of wastes, especially the liquid discharges. These wastes can alter the physical, chemical and biological nature of the receiving water body that usually has an ultimate characteristic correlation with the subsequent aquifer (Ntuli et al., 2011).

Groundwater is often considered as a reliable source of fresh water which is easily accessible near to the point of consumption. It is generally believed that groundwater is purer and safer than surface water due to protective earth crust shield (Saravi et al., 2013). At 
the same time, the economic upgradation has resulted in severe impacts on groundwater characteristics. The indiscriminate disposal of industrial effluents and leachates from landfills had caused considerable decline in the groundwater quality (Rajkumar et al., 2012). Numerous methodologies have been raised to approximate groundwater vulnerability and pollution threats over varying hydrogeological conditions (Al-Adamat et al., 2003). But still, a worldwide approach for the assessment of probable risks has not been forwarded yet.

The natural circumstances that affect the groundwater system include climatic parameters like temperature, rainfall, evapo-transpiration etc., whereas anthropogenic actions include excessive groundwater pumping and percolation of contaminated fluids due to offensive management of industrial effluents and irrigation systems (Kumar 2012). Groundwater pollution caused due to these contaminated recharges results in irreversible damages to soil, cropping system and entire biological realm. Consequently, contaminated drinking water is the major source for the spread of epidemic and chronic diseases in the native population. Risks may change over time, particularly when pollutants tend to accumulate. Their prolonged exposures probably result in skin ailments, typhoid, jaundice, dysentery, diarrhea, tuberculosis etc. (Patel et al., 2010).

Groundwater quality monitoring is a fundamental element of any effort to integrate groundwater science with water-management decisions. Monitoring provides the necessary data that aids in water-governance (Alley 2007). The State Infrastructure and Industrial Development Corporation of Uttarakhand Limited Industrial Estate (SIDCUL-IE) was established in year 2006 in Haridwar district of Uttarakhand state in northern India. The expansion of industrial establishments in SIDCUL-IE is being continuing since last seven to eight years. Since the commissioning of industrial complex, a number of processing and production industries have been established including apparel, agro food, cosmetics, plastic, pharma-products, electric and electronic products, packaging, synthetic fabrics, electroplating, commercial automotives etc. In context to the newly established industrial estate, no major study concerning the assessment of impacts of industrial wastes particularly effluents on groundwater has been carried out till date.

In the recent past, many researchers have carried out different studies concerning the impact of different industrial and developmental activities on groundwater quality like Leung and Jiao (2006) in Mid-levels area, Hong Kong; Dimitriou et al., (2008) at Athens, Greece; Karunakaran et al., (2009) at Namakkal, India; Bhaskar et al., (2010) at Tumkur, India; Rajappa (2010), Hakinaka Taluk, Davangere, India; Nubi and Ajuonu (2011), at Oyo state, Nigeria; Fazila et al.,
(2012), at Beed City, India; Ramesh et al., (2012), Bangalore, India; Bhadra et al., (2013), Pali City, India; Sekhon and Singh (2013) at Patiala, India and Venkateswarlu (2014) at Hyderabad, India etc. But there are no reports available regarding the characteristic dynamics of groundwater quality resulting from of distressing industrial activities at SIDCUL-IE, Haridwar. Central Pollution Control Board (CPCB) has forwarded the concept of Comprehensive Environmental Pollution Index (CEPI) for Industrial Clusters in India, which intend as an early warning tool for pollution potential of any industrial realm. This index captured various health dimensions of environment including air, water and land. The district Haridwar ranks $73^{\text {rd }}$ (among 88 major industrialized districts) in India in terms of pollution potential of its industrial cluster with CEPI score of 61.01. The districts with CEPI range of 60-70 were considered as severely polluted areas. Further, CPCB recommends a periodic surveillance for designing and implementation of pollution abatement measures in Haridwar. Keeping above in view, the present study was conducted with the objective to monitor temporal and spatial dynamics in groundwater quality and its potential health risks ensuing industrial distress of untreated effluent discharge at SIDCUL Industrial Estate at Haridwar, India.

\section{MATERIALS AND METHODS}

Study area: SIDCUL-IE is a densely industrialized complex in district Haridwar with major industrial set-ups (Fig.1). Geographically, the industrial area is located within latitude $29^{\circ} 94^{\prime}$ in the north to longitude $78^{\circ} 16^{\prime}$ in the east with an elevation of $370 \mathrm{~m}$ above mean sea level. The complex has a vast expanse of about 823.13 hectares with more than seven hundred independent industrial units in operation. SIDCUL-IE serves as a transition zone between two major geological formations viz; the hard rock relief (Shivalik ranges) and the alluvial terrains (with a steep gradient). On the basis of regime, the quality of ground water in both these reliefs would be strictly different. Consequently, there is high probability of natural variation in groundwater characteristics at SIDCUL-IE. Simultaneously, the groundwater system is susceptible to multiple factors, therefore a holistic approach integrating climate, temperature, hydrogeology and geochemistry needs to be considered while studying the different processes responsible for the contamination of the groundwater resources along with the anthropocene.

Climate and temperature: The district Haridwar experiences moderate subtropical to humid climate with three different seasons viz. summer followed by rainy and winter season. Temperature begins to rise in March $\left(29.1^{\circ} \mathrm{C}\right)$ and reaches to its maximum in May $\left(39.2^{\circ} \mathrm{C}\right)$. With the beginning of monsoon season by mid of June, the temperature begins to fall. During the winter season, in the month of November to February, the temperature ranges between $10.5^{\circ} \mathrm{C}$ and $6.1^{\circ} \mathrm{C}$ 


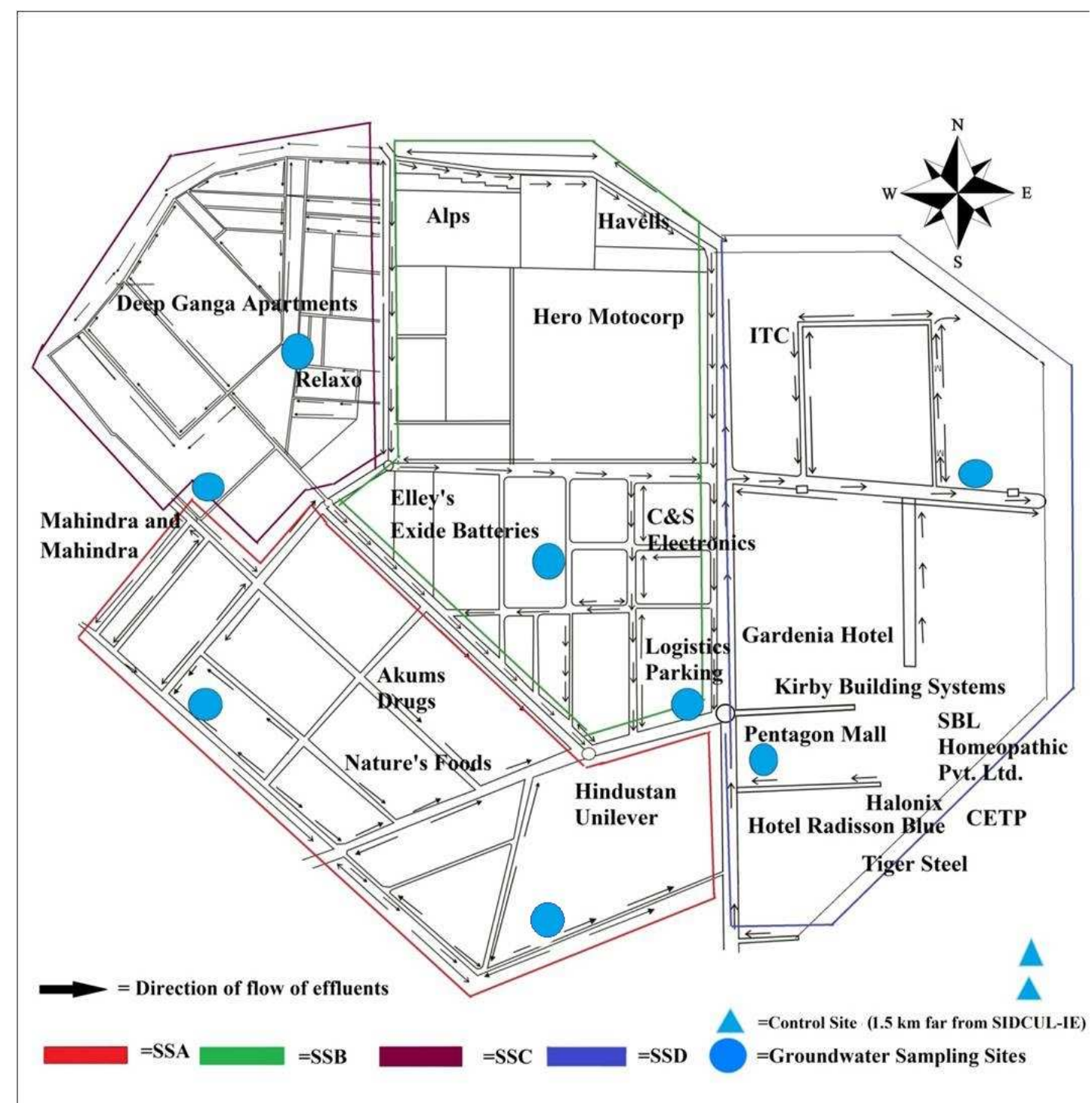

Fig.1. Showing groundwater sampling sites at SIDCUL-IE

(CGWB 2009).

Hydrogeology and rainfall: The alluvium is chief water bearing strata in the region consisting of coarse sand, fine sand and silt. Groundwater in Haridwar district occurs under unconfined, confined and semi-confined conditions. The aquifers are separated with thick clay with considerable thickness, which act as confining layers. The water level studies conducted by Central Ground Water Board, India, suggests the presence of multilayer aquifer system. Generally, the ground water abstraction structures in the district are shallow and deep tube-wells with depth ranging from 60 to 150 meters below ground level. The SIDCUL-IE region along the foothills of Shivalik range consists of boulders, gravels, sand and clay, which characterize high permeability and porosity. This feature makes it a fine recharge zone through the direct infiltration of precipitation. The average annual rainfall in the district is $1174.3 \mathrm{~mm}$, of which $84 \%$ is received during monsoon and $16 \%$ occurs during non-monsoon period. Rainfall is the chief source that sustains the groundwater in Haridwar (CGWB 2009).

Sampling procedure: In view of a large study area, the SIDCUL-IE was divided into four sampling stations (SS), named as Sampling Station-A (SSA), Sampling Station-B (SSB) Sampling Station-C (SSC) and Sampling Station-D (SSD). Grab samples of groundwater were taken from the bore-wells within the industries and hand-pumps (India Mark-II) installed for public use. On the basis of availability, two sampling sites were identified in each sampling station for the sampling of groundwater. Thus eight groundwater samples were collected for physico-chemical characterization. Two control samples of groundwater were taken from Shivalik 
Nagar (Residential area), situated at the distance of about 2 kilometers from SIDCUL-IE. Monthly sampling was carried out from February 2013 to January 2014 (between 9.00 am to $12.00 \mathrm{pm}$ ). The eight sampling locations within the study area are demarcated in figure 1. The groundwater samples were collected from taps and hand-pumps after flushing water for 5-10 min. The samples were collected in 2.5 liter capacity high density polyethene (HDPE) bottles that were pre-washed (rinsed 4-5 times with distilled water) and dried before use. All the samples were immediately transported to the laboratory and were stored at $4^{\circ} \mathrm{C}$ till analysis. During the sampling procedure, the precautions were taken as per the standard guidelines of APHA (2012) to avoid possibility of any contamination.

Analytical procedure: The $\mathrm{pH}$ and total dissolved solids (TDS) in groundwater samples were determined using microprocessor based digital water and soil analysis kit (ESICO, Model-1160). Temperature was recorded using digital thermometer (Maxtech, multi thermometer). Turbidity was measured in Nephelometric turbidity unit (NTU) using turbidity meter (ESICO, Model-335). Other parameters like, dissolved oxygen (DO), biochemical oxygen demand (BOD), total hardness (TH), chemical oxygen demand (COD), bicarbonates $\left(\mathrm{HCO}_{3}{ }^{2-}\right)$, acidity and alkalinity were calculated by titrimetric analysis whereas the total solids (TS) and total suspended solids (TSS) were analyzed by gravimetric analysis. Potassium (K) was determined using microprocessor based flame photometer (ESICO, Model-1382) while phosphorus (P) was estimated by UV-Vis spectrophotometer (Agilent, Model- Cary 60). The analysis of the above mentioned parameters was done in triplicate following the standard methods of APHA (2012).

Statistical Analysis: The observed data subjected to statistical analysis for the mean, standard deviation (SD) and Karl Pearson Correlation matrix for the characteristic correlations of different physic -chemical parameters was calculated using MS Excel 2007.

\section{RESULTS AND DISCUSSION}

The mean $\pm \mathrm{SD}$ values of various parameters of groundwater samples and the Control samples investigated in this study during February 2013 to January 2014 are given in Table 1 to 5 . The correlation matrix of different parameters of various sampling stations and the control is shown in Tables 6 to 10 . Health risk assessment was accomplished by comparing the observed groundwater quality data with drinking water standards and regulations laid down by the regulatory bodies and health agencies. The health impacts were predicted on the basis of the earlier studies concerning the same aspect.

pH: The $\mathrm{pH}$ of a solution is defined as the logarithm to the base 10 of the reciprocal of the $\left(\mathrm{H}^{+}\right)$ion concentration
(Barrett et al., 2010). The pH is greatly influenced by the temperature of water. In the present study, the $\mathrm{pH}$ of groundwater samples was observed to be quite acidic (6.35) at sampling station A (SSA) in the month of October whereas the $\mathrm{pH}$ was relatively alkaline (8.17) at sampling station B (SSB) in the month of March. In control groundwater samples, the $\mathrm{pH}$ range was observed between within the prescribed limits i.e. 7.23 in July to 8.1 in the month of May. These observations are similar to the range values (6.4-8.5) determined by Rameeza et al., (2012) in a study of ground water quality in industrial zone of Visakhapatnam. Though, pH generally does not have a direct effect on consumers yet it is a crucial operational water quality parameter. The maintenance of an even hydrogen ion $\left(\mathrm{H}^{+}\right)$concentration in body fluids is necessary for survival. In healthy individuals, plasma $\mathrm{pH}$ is slightly alkaline and maintained in the narrow range of 7.35 to 7.45 (Barrett et al., 2010). The consumption of drinking water with lower $\mathrm{pH}$ (below 4) may possibly cause irritation in eyes, skin, and mucous membranes while exposure to extreme lower $\mathrm{pH}$ values (approximately 2.5) may lead to irreversible and extensive damage to epithelium (WHO 1986). The $\mathrm{pH}$ range of 10-12.5 has been reported to cause swelling in hairs whereas higher $\mathrm{pH}$ values (above 11) may have similar symptoms mentioned above for lower $\mathrm{pH}$ values (below 4). On the other hand, gastrointestinal irritation may also occur in susceptible (new born and elderly) individuals (WHO 2003). Beside health perspectives, $\mathrm{pH}$ can affect the degree of corrosion of metals (pipes in distribution systems) as well as disinfection efficiency which may have an indirect effect on human health as well as on the treatment systems.

Temperature: The temperature of water is the vital parameter that affects the chemistry of water thereby causing variation in $\mathrm{pH}$, turbidity, alkalinity, hardness and dissolved carbon dioxide $\left(\mathrm{CO}_{2}\right)$. Temperature also has a great effect on biological system as it influences the metabolic activities of an organism. An increase in the temperature of water proportionally increases the rate of biochemical reactions. In this study, the groundwater samples with lowest temperature $\left(22.9^{\circ} \mathrm{C}\right)$ were observed at SSC in the month of December whereas the highest temperature $\left(31.4^{0} \mathrm{C}\right)$ of water samples was recorded at SSB in May. The temperature of control samples ranged from $24.8^{\circ} \mathrm{C}$ in February to $29.9{ }^{0} \mathrm{C}$ in the month of May. The observed values of temperature are similar to the observations $\left(22-31^{\circ} \mathrm{C}\right)$ of Karunakaran et al., (2009), who studied the physic -chemical characteristics of groundwater at Namakkal, India. Although, the drinking water temperature does not bear a direct relationship with human health, but in terms to palatability, a limit of $\leq 15^{\circ} \mathrm{C}$ has been ascertained. The activation energy of most chemical reactions is associated up to this temperature range (Health Canada 1995). The rise in temperature increases the vapour pressure of trace volatile organics 
in drinking water which may result in increased odor (APHA 2012). The growth of disease causing microbes is also enhanced by warm water. Legionella pneumophila is extensively found in water environments which can multiply at temperature above $25^{\circ} \mathrm{C}$. This waterborne pathogen was responsible for legionellosis, with two clinical identified forms: Legionnaires' disease (pneumonic illness) and Pontiac fever (WHO 2011).

TS, TSS, TDS: The solids indicate the presence of various minerals in water. Total solids constitute suspended and dissolved solids as well. TSS are the solids which are retained by a glass fiber filter and dried to a constant weight at $103-105^{\circ} \mathrm{C}$ whereas, TDS refers to the dissolved inorganic salts and traces of organic matter in water as a solution. The key constituents of TDS include dissolved calcium, magnesium, sodium $\left(\mathrm{Na}^{+}\right)$and $\mathrm{K}^{+}$cations and carbonate, hydrogen carbonate, chloride, sulfate, and nitrate anions (WHO 2007). Naturally, most of the dissolved constituents in groundwater are due water-rock interactions occurring within a lithological outline. Aesthetically, an objective of $\leq 500 \mathrm{mg} / \mathrm{L}$ has been established for TDS in drinking water. At higher concentration, water may become excessively hard, non-palatable, while corrosion may also occur in plumbing networks as a consequence of mineral deposition (Health Canada, 1991).

In the present study, the minimum values of TS (170 $\mathrm{mg} / \mathrm{l})$, TSS $(23.5 \mathrm{mg} / \mathrm{l})$ and $\operatorname{TDS}(85.5 \mathrm{mg} / \mathrm{l})$ were observed at SSC and SSB in April; and SSD in October, while the maximum values of TS $(1000.0 \mathrm{mg} / \mathrm{l})$, TSS (694.0 $\mathrm{mg} / \mathrm{l})$ and TDS $(553.5 \mathrm{mg} / \mathrm{l})$ were recorded at SSD, SSD and SSC in the month of November respectively. The solids in the control samples of groundwater ranged as, TS from 280.80 $\mathrm{mg} / \mathrm{l}$ in May to $1000.74 \mathrm{mg} / \mathrm{l}$ in November, TDS from $220.0 \mathrm{mg} / \mathrm{l}$ in October to $538.0 \mathrm{mg} / \mathrm{l}$ in January and TSS from $8.0 \mathrm{mg} / \mathrm{l}$ in October to $517.32 \mathrm{mg} / \mathrm{l}$ in November. The recorded values of TDS and TSS were extremely higher as compared to the observations of Uhegbu et al. (2012) for TDS (3.65- $72.35 \mathrm{mg} / \mathrm{l})$ and TSS (2.95-15 mg/l) in assessment of groundwater quality at Aba Metropolis, Nigeria. In different epidemiologic studies, it has been reported that moderately high TDS level (below 1,000 mg/L) protected consumers against cancer and heart disease (Schroeder 1960; Burton and Cornhill 1977; Craun and McCabe 1975 and Monarca et al., 2006), but the mechanism(s) underlying these observations are not completely understood. While the constituents of TDS, markedly $\mathrm{Mg}$ hinders with the formation of thrombi in arteriosclerosis (Sauvant and Pepin 2002 and Monarca et al., 2006). Although, World health organization (WHO) has not proposed any health-based guideline values for TDS in drinking water but the presence of dissolved solids may affect its taste. The palatability of drinking water in relation to its TDS content can be classified as: excellent, i.e. less than $300 \mathrm{mg} / \mathrm{litre}$; good, between 300 and $600 \mathrm{mg} / \mathrm{litre}$; fair, between 600 and $900 \mathrm{mg} / \mathrm{litre}$; poor, between 900 and 1200 $\mathrm{mg} / \mathrm{litre}$; and unacceptable, greater than $1200 \mathrm{mg} / \mathrm{liter}$ (WHO 2003).

Turbidity: Turbidity is measure of the transparency in water. Turbidity in groundwater is caused due to the presence of inorganic particulate matter as suspension. These materials may be clay, silt, organic matter, salts and some microscopic organisms (Momba et al., 2006). Turbidity does not have any direct effect to human health rather; the particulates responsible for turbidity can protect microorganisms from the effects of disinfection and can also stimulate bacterial growth. The water with a turbidity of less than 5 NTU is generally acceptable to consumers but this may vary with specific conditions (WHO 2008). In this study, the turbidity in the groundwater samples was observed to be nil at many sampling sites almost all the time while maximum turbidity (5.7 NTU) was recorded at SSD in the month of November. In control samples, the values of turbidity ranged from 0 to 1.0 NTU. Turbidity was found within the prescribed limits in all the water samples. The observed results were quite higher (0.5-0.79 NTU) than the observations of Abbulu and Rao (2013) in assessment of physico-chemical characteristics of groundwater in the industrial zone of Visakhapatnam, India. Turbidity is a crucial indicator of groundwater quality variations, particularly under the influence of percolation from surface. The aquifers experience rapid changes in terms of water quality, during the recharge periods (Martin et al., 2008). Consequently, this may be also applicable for the seepage of industrial effluents from the industrial complex drainage system which possibly alters the turbidity of groundwater at SIDCUL-IE. Some recent health studies investigating the outbreak of drinking water turbidity showed a potential association of turbidity with gastro-intestinal illness (Mann et al., 2007).

DO: DO concentration has a considerable impact upon ground water quality. It regulates the valance state of trace metals and restricts bacterial metabolism of dissolved organic matter (Rose and Long 1988). The presence of sufficient oxygen in drinking water supplies is necessary, as it aids the formation of protective layer inside metal pipes in public distribution system. This needs an optimum DO concentration of 6-8 mg/L (Lenntech 2014a). DO in the groundwater samples was observed to be minimum $(3.0 \mathrm{mg} / \mathrm{l})$ in August at SSC, simultaneously the maximum value $(8.35 \mathrm{mg} / \mathrm{l})$ of DO was recorded at the same sampling station in the month of January. In the control samples of groundwater, the minimum value of DO $(5.6 \mathrm{mg} / \mathrm{l})$ was recorded in the month of April and May, whilst maximum value of DO $(7.0 \mathrm{mg} / \mathrm{l})$ was observed in the month of March. Similar DO range (5.6-7.1) in groundwater samples was observed by Rameeza et al. (2012) in an industrial area at Visakhapatnam, India. Ahmed et al. (2010) also observed nearly same range 


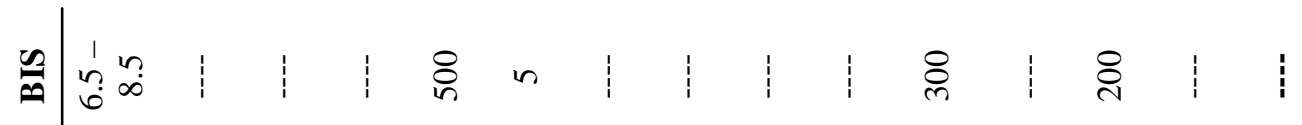

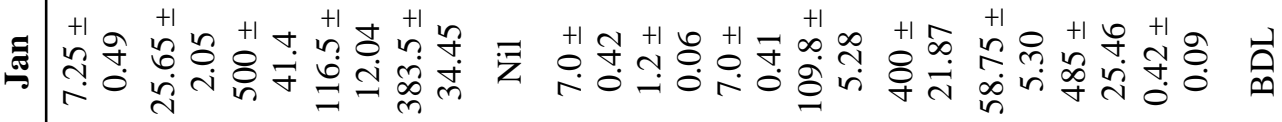

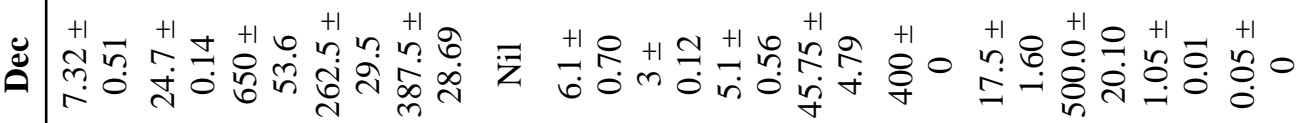

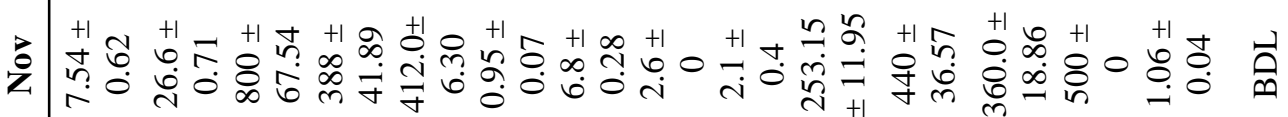

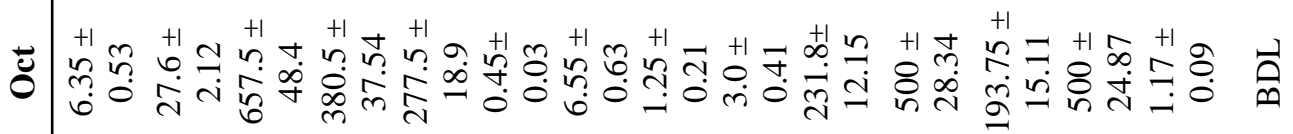

ڤ̆

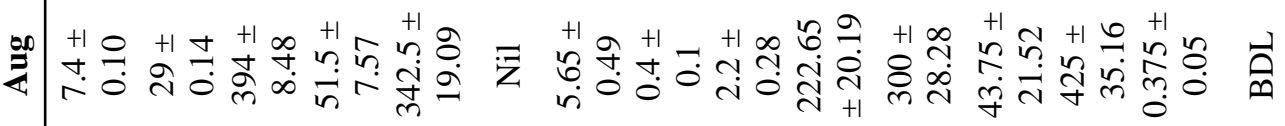

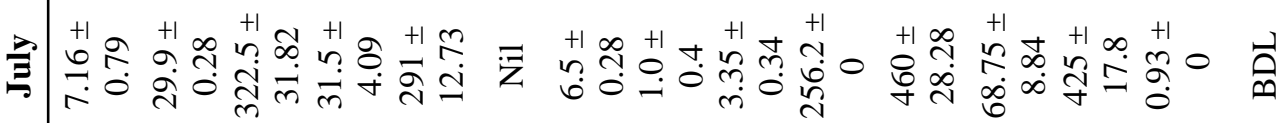

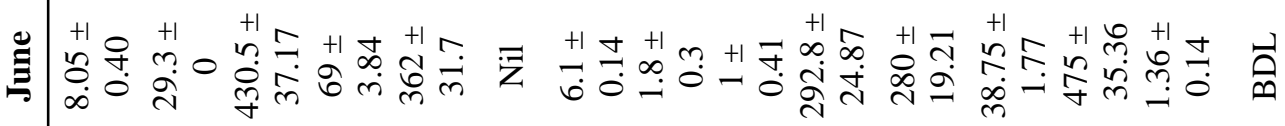

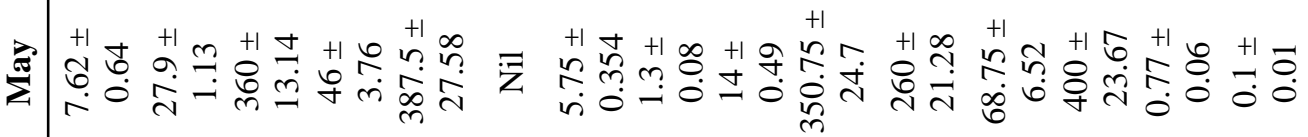

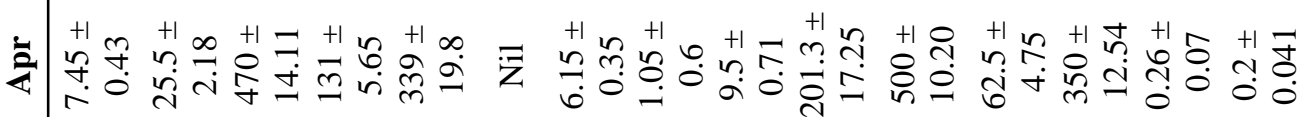

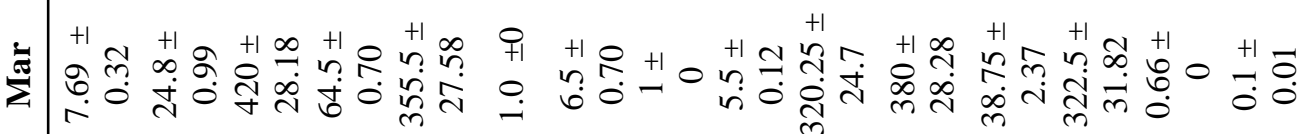

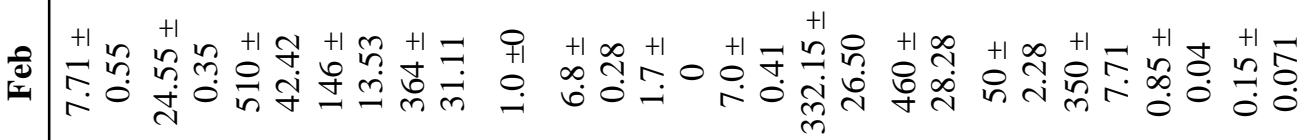

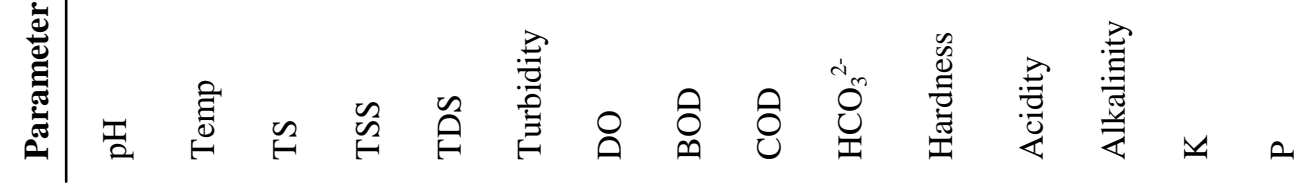




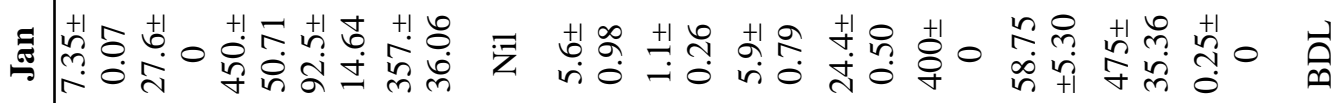

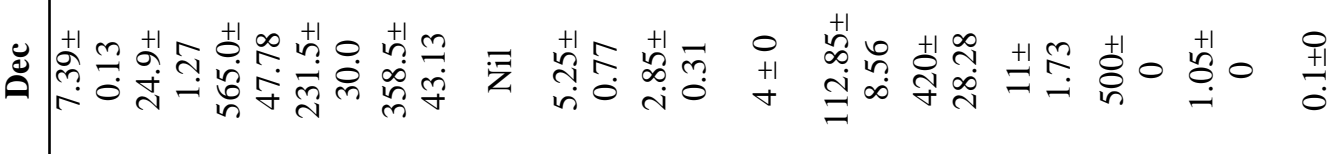

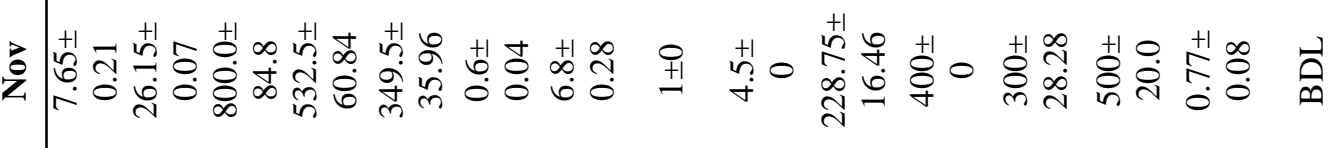

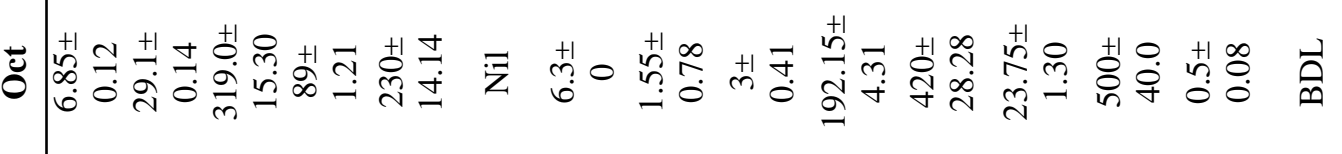

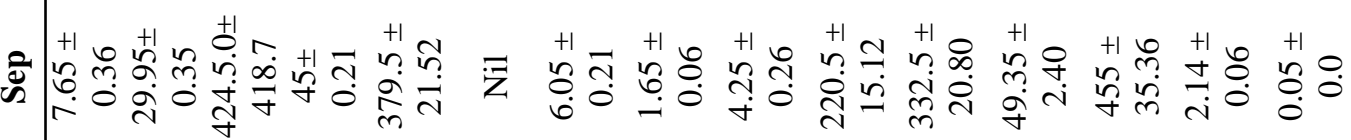

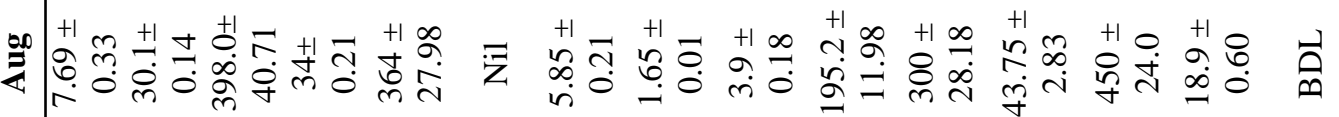

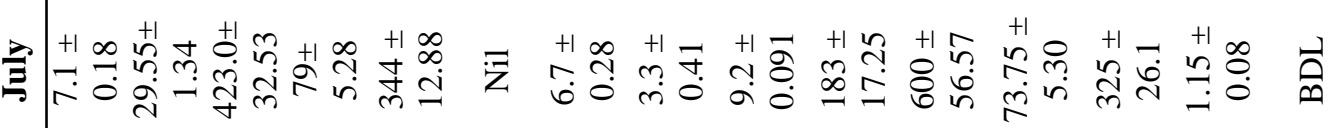

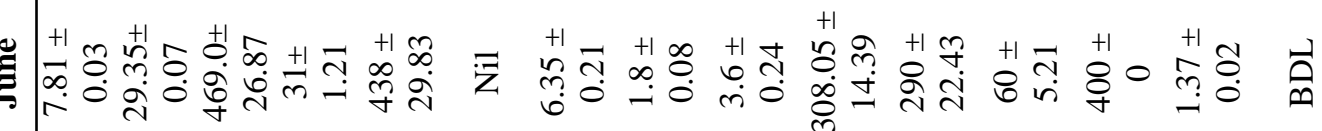

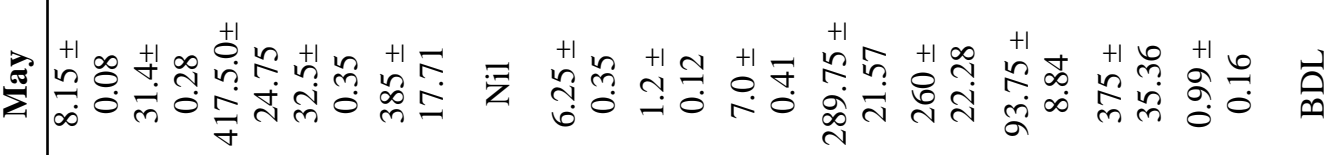

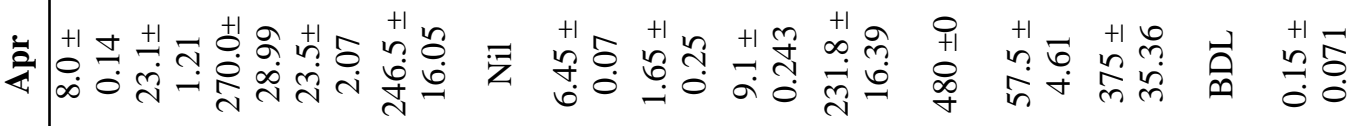

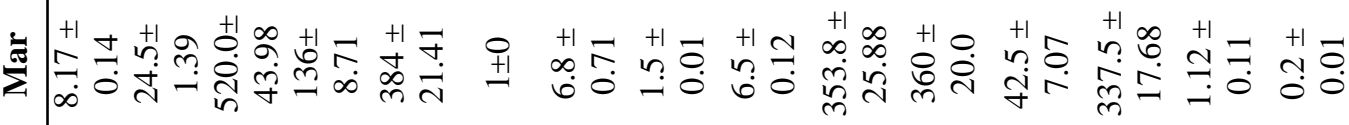

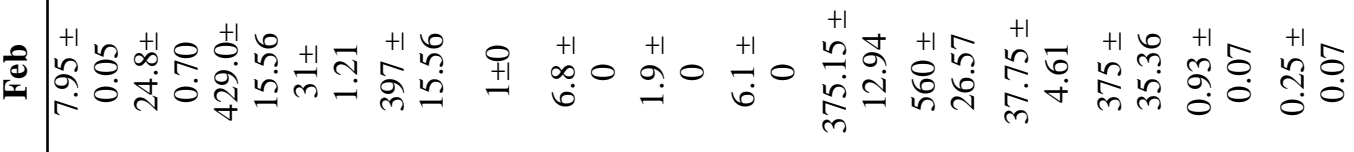

罍

:

恣命高

○ 。

8ิ

莺咅

齐 


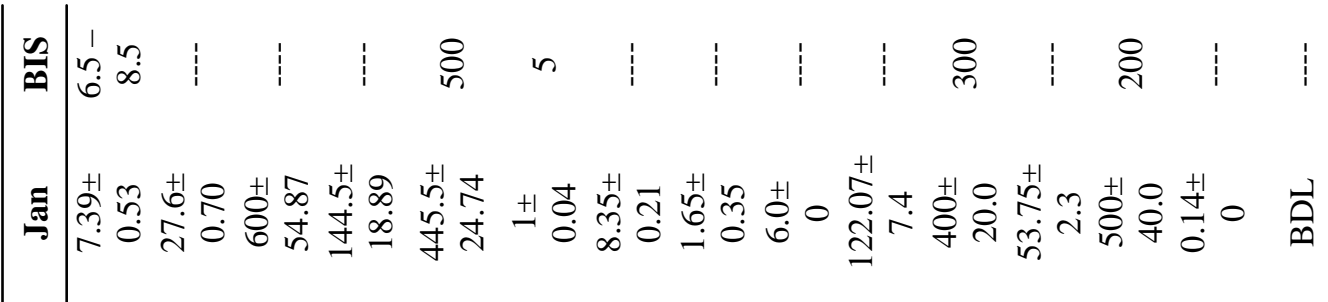

岁

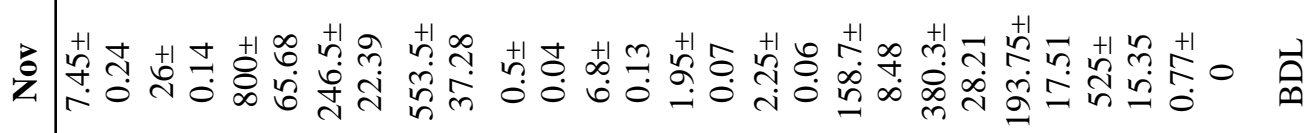

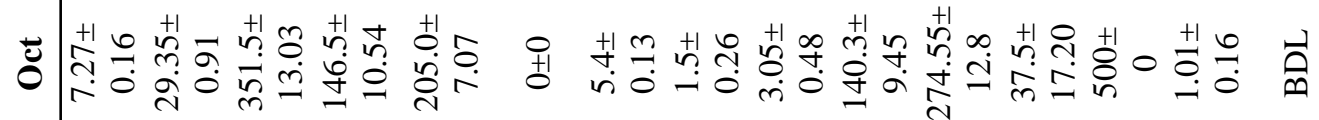

ڤึ

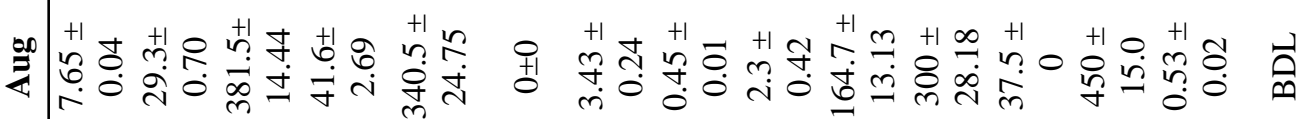

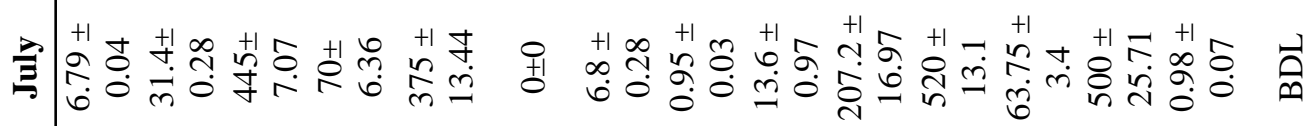

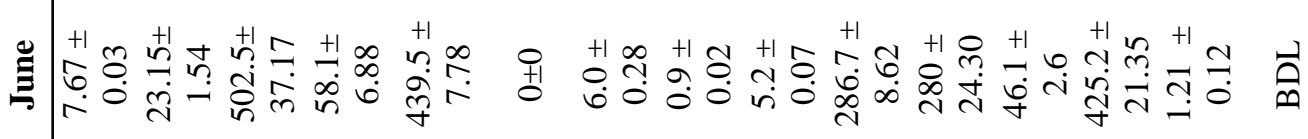

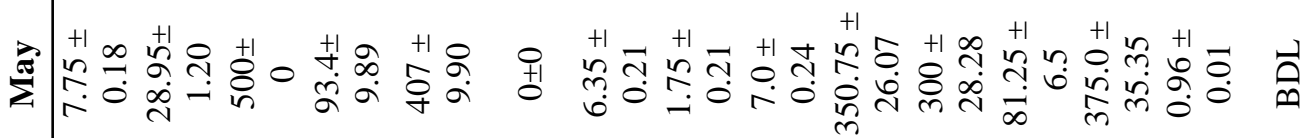

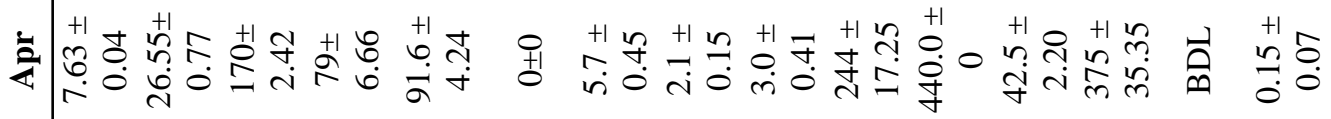

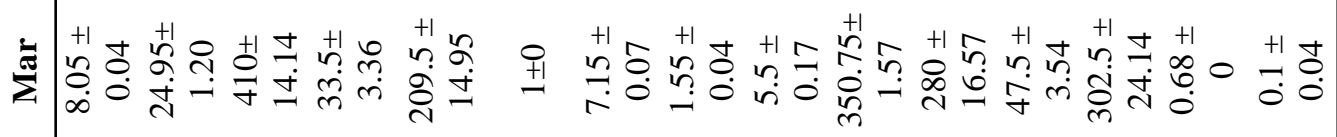

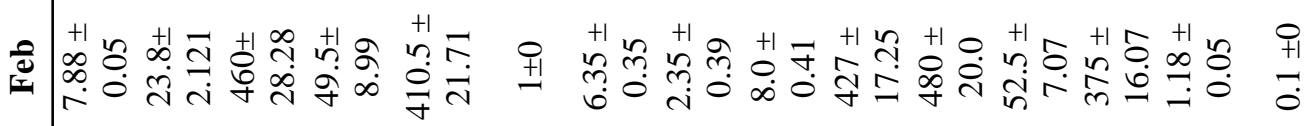

I 


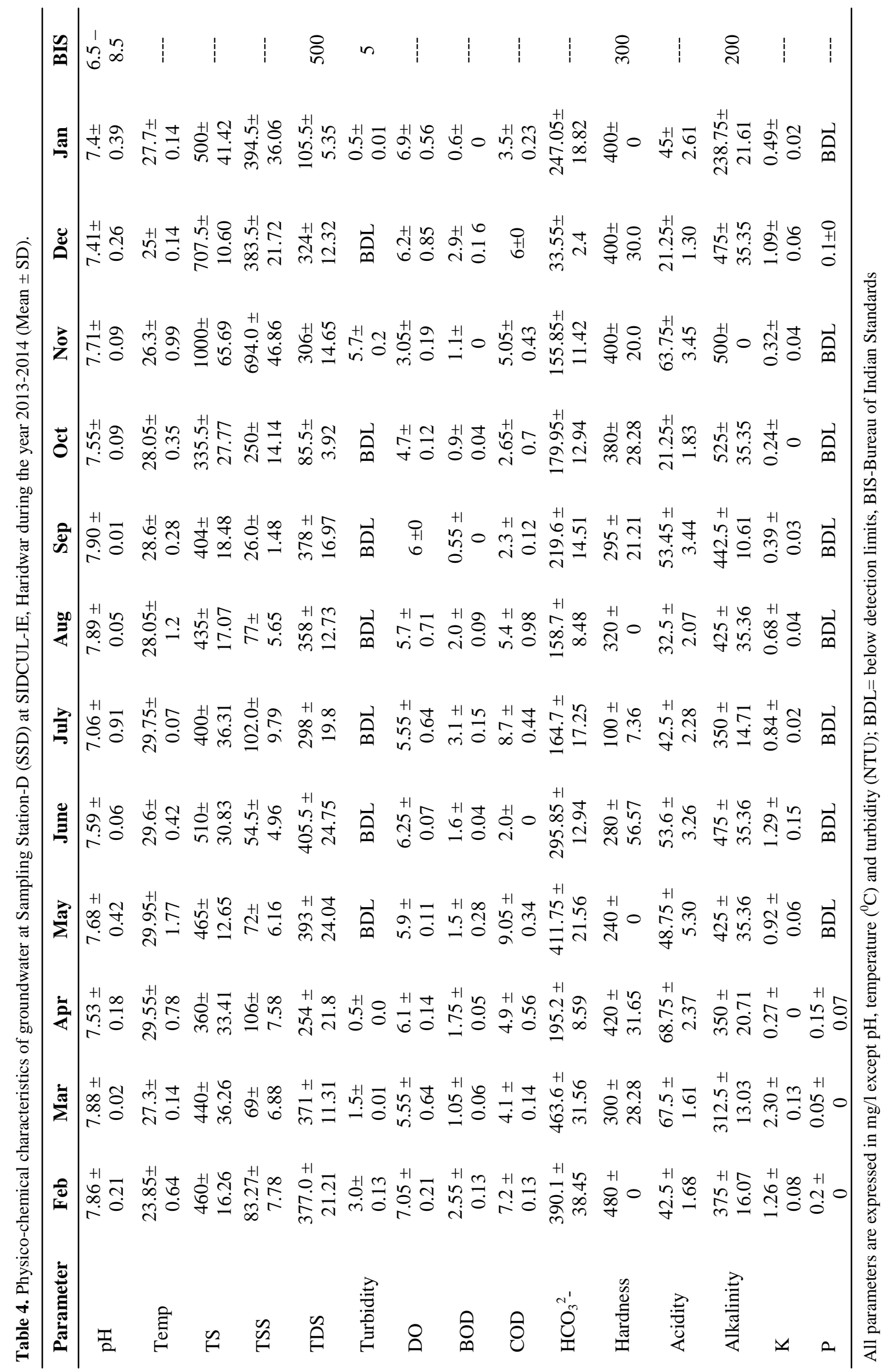




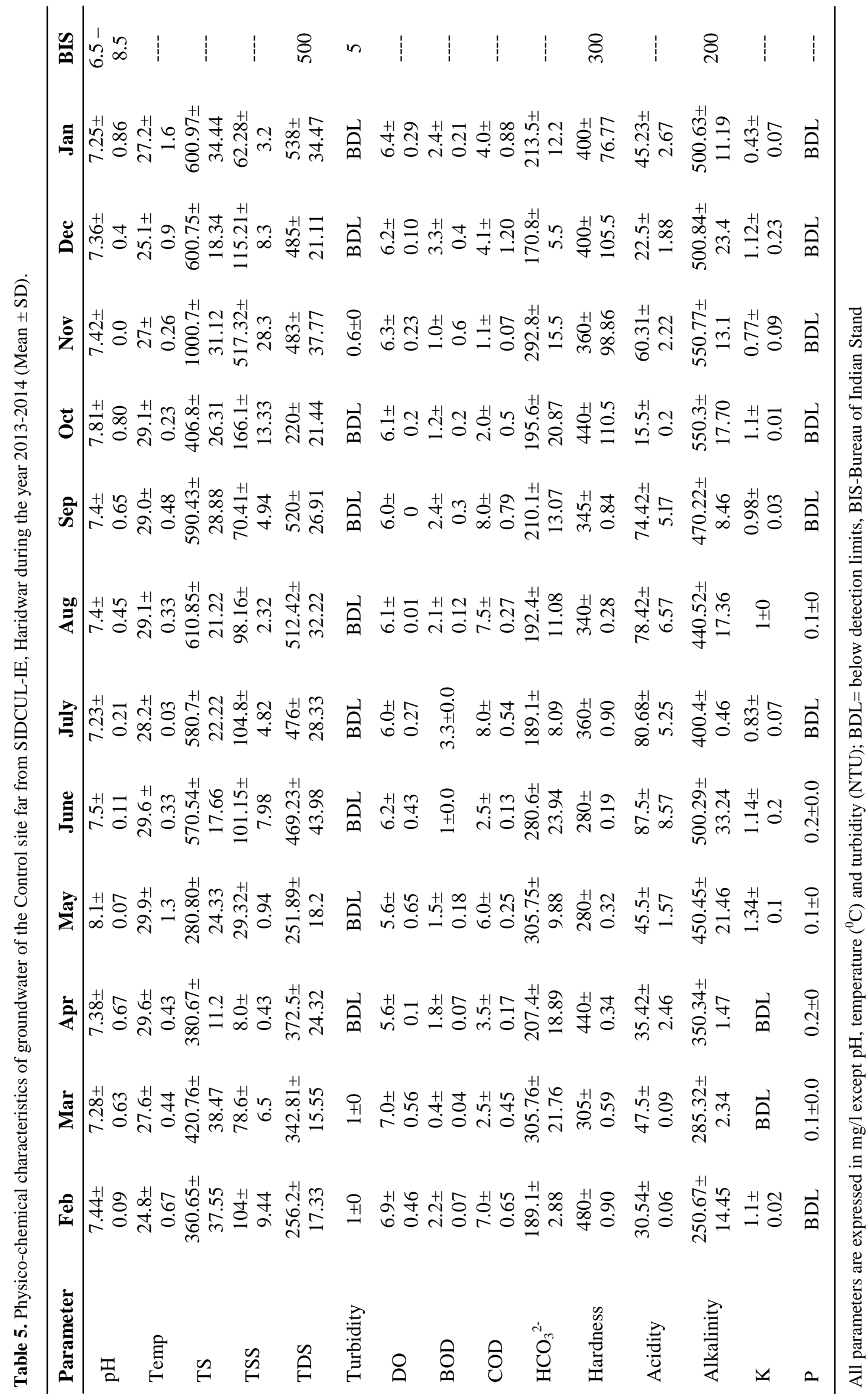



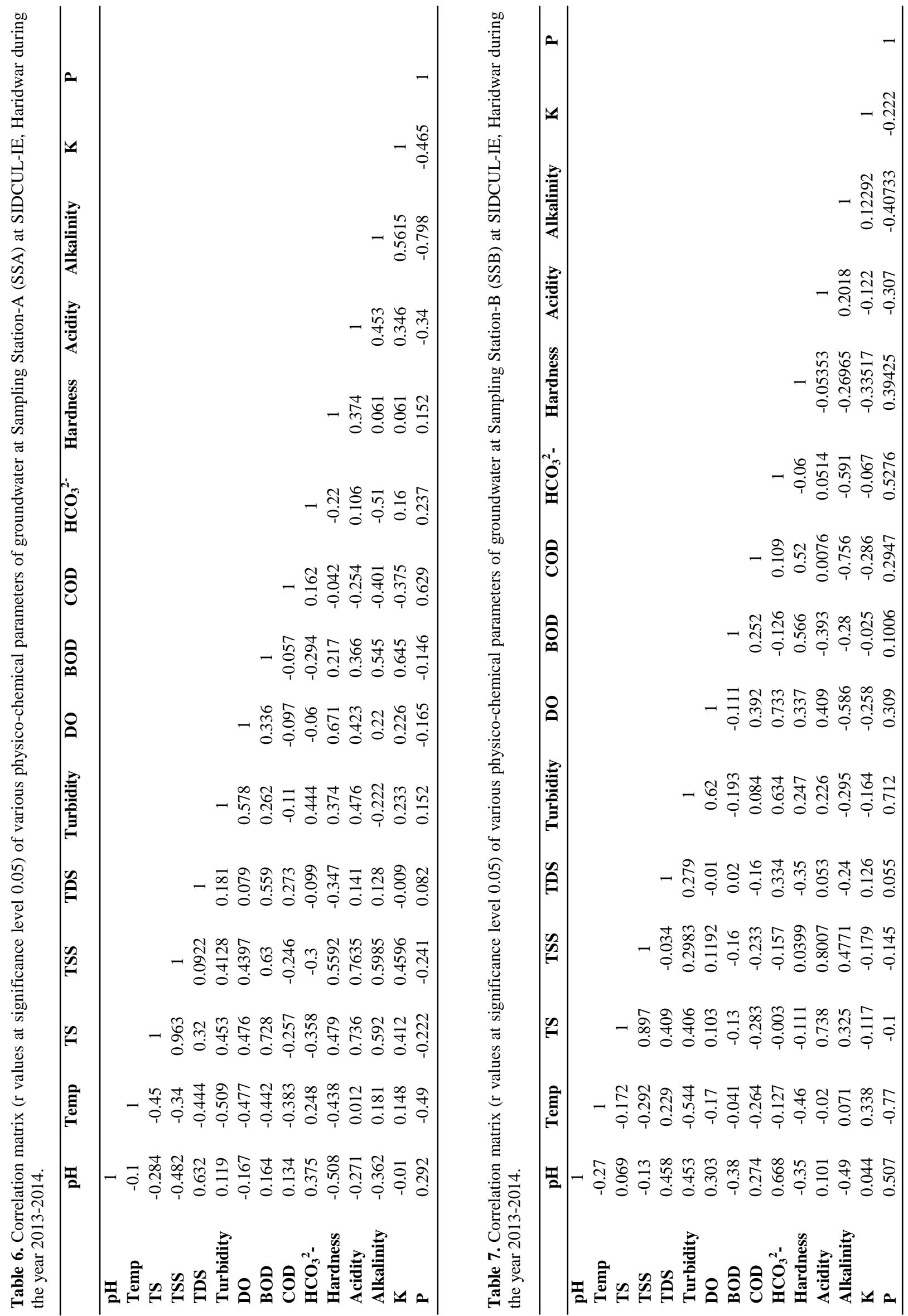
of DO (4.91-7.56) in groundwater samples in a study of assessment of surface and groundwater quality at Chittagong region of Bangladesh. The DO concentration level does not have any direct effect on human health; rather it may lead to leaching of toxic heavy metals in water-supply pipes, thereby causing indirect impacts to human health.

BOD: BOD is a quantitative indicator of the biologically degradable organic substances in water. It is widely used to assess strength of pollutants in aquatic systems. The minimum value of BOD $(0.4 \mathrm{mg} / \mathrm{l})$ in groundwater samples was observed at SSA in August, whereas the maximum value of BOD $(3.3 \mathrm{mg} / \mathrm{l})$ was recorded at SSB in the month of July. In control samples, the BOD ranged from $0.4 \mathrm{mg} / \mathrm{l}$ in March to $3.3 \mathrm{mg} / \mathrm{l}$ in the month of July. The lower BOD value in all groundwater samples indicated good sanitary condition of the water. The observations for BOD in the present study are significantly lower than the BOD (2.68-10.07 mg/l) reported by Khanam and Singh (2014) in assessment of groundwater quality near a polluted canal area in Kichha, district Udham Singh (U.S.) Nagar, India. High BOD in groundwater indicates its faecal contamination. Kumar et al. (2011) observed a strong positive correlation of BOD with total coliforms (0.52) and fecal coliforms (0.36) as well. E. coli can cause serious diseases, such as urinary tract infections, bacteraemia, gastroenteritis and meningitis (Ashbolt 2004 and WHO 2011). In general, higher values of BOD in drinking water may cause serious health impacts, but the BOD values in this study were considerably in safer limits.

COD: COD is the equivalent of oxygen required by the organic substances in water to oxidize them by a strong chemical oxidant. In this study, the minimum COD in the groundwater $(1.0 \mathrm{mg} / \mathrm{l})$ was observed at SSA in the month of June simultaneously, the maximum value of COD (14.0 $\mathrm{mg} / \mathrm{l})$ was recorded at same sampling station in the month of May. In control samples, the COD varied from $1.1 \mathrm{mg} / \mathrm{l}$ in November to $8.0 \mathrm{mg} / \mathrm{l}$ in July. The observed values were considerably higher $(3.1-3.7 \mathrm{mg} / \mathrm{l})$ than the values reported by Sirajudeen et al. (2014) in a study of groundwater contamination carried out at Tirunelveli, India. Higher COD in groundwater indicates the presence of non-biodegradable dissolved organic carbon (DOC). The high incidence of DOC causes undesirable color, taste and odor in drinking water (Sagehashi et al., 2005). It also interferes with the disinfection process and results in toxic disinfection by-products (DBPs) such as trihalomethanes (THMs) and haloacetic acids (HAAs) (White et al. 2003; Wong et al., 2007; Chow et al., 2008; Ratasuk et al., 2008; Krasner 2009; Matilainen et al., 2010 and 2011). DPBs have been reported to pose harmful effects on human health (Hanson and Solomon 2004; Zhou et al., 2006; Jung and Son 2008 and Wu et al., 2009). These byproducts had also been identified as a potential fetotoxin, mutagen and carcinogen as well (Ruddick et al., 1983;
Reckhow et al., 1990 and Bryant et al., 1992).

Bicarbonates: Bicarbonates are the standard alkaline constituents found in almost all ground waters that affect alkalinity and hardness of water. Naturally, the rock-weathering process adds bicarbonates in groundwater but the concentration of bicarbonates in water relies on $\mathrm{pH}$ and is usually observed to be less than $500 \mathrm{mg} / \mathrm{l}$ in groundwater. Any standard for permissible limit of bicarbonate concentration in drinking water is not recommended by $\mathrm{WHO}$, while it is considered to be not more than $500 \mathrm{mg} / \mathrm{l}$. In this study, the minimum concentration of bicarbonates $(33.55 \mathrm{mg} / \mathrm{l})$ in groundwater was observed at SSD in the month of December at the same time the maximum concentration of bicarbonates (463.6 mg/l) was observed at same sampling station in the month of March. In control samples, the bicarbonates ranged from $170.8 \mathrm{mg} / \mathrm{l}$ in December to $305.75 \mathrm{mg} / \mathrm{l}$ in the month of March. Ramesh and Seethe (2013) also reported similar results for the highest limit of bicarbonates (207.4-488 mg/l) in groundwater samples from a tannery industrial complex Vellore, India. Prabha et al. (2013) also reported nearly similar values for the maximum concentration (159-471 $\mathrm{mg} / \mathrm{l})$ of bicarbonates in groundwater at an industrial area in Tirupur India. Bicarbonate ingestion causes changes in acid-base balance, blood $\mathrm{pH}$ and bicarbonate concentration in biological fluids. Coen et al. (2001) suggested that consumption of bicarbonate-rich water lowers the risk of calculus formation in urine. In contrast, Lutai (1992) reported higher incidence of goiter, hypertension, ischemic heart disease, gastric and duodenal ulcers, chronic gastritis, cholecystitis and nephritis due to consumption of mineral deficient water.

Total hardness: Hardness refers to the sum of concentration of polyvalent cations dissolved in the water. Calcium $\left(\mathrm{Ca}^{2+}\right)$ and magnesium $\left(\mathrm{Mg}^{2+}\right)$ are the most common polyvalent cations that are frequently present in groundwater. Ferrous $\left(\mathrm{Fe}^{2+}\right)$ and manganese $\left(\mathrm{Mn}^{2+}\right)$ ions also contribute to groundwater hardness (Jain and Jain 1990). The hardness in groundwater water is generally due to the interaction of subsurface water with the soil media and rock formations. The concentration range for pleasant taste due to the calcium ion depending on the associated anion is 100-300 mg/L, but higher concentrations are also acceptable to consumers. Hardness values above 500 $\mathrm{mg} / \mathrm{L}$ are usually aesthetically non-agreeable (Zoeteman 1980). In the present study, the hardness in groundwater samples was observed to be minimum $(100 \mathrm{mg} / \mathrm{l})$ at SSD in July, while the maximum value of hardness $(600.0 \mathrm{mg} / \mathrm{l})$ was recorded at SSB in the month of July. Hardness in the control samples varied between $280.0 \mathrm{mg} / \mathrm{l}$ in June to $480.0 \mathrm{mg} / \mathrm{l}$ in the month of February, whereas the permissible limit of hardness for drinking water is $300 \mathrm{mg} / \mathrm{l}$. However, it is important to note that total hardness in groundwater was higher at all sampling sites all the time. Reddy et al. (2013) also reported relatively higher $(302-752 \mathrm{mg} / \mathrm{l})$ 
values of hardness in groundwater samples of an industrial belt at Visakhapatnam, India.

There does not appear any influential study in the past, correlating the drinking water hardness with adverse health effects in humans. Rather, drinking water calcium plays a key role in a number of physiological functions like suppression of neuromuscular excitability, myocardial function, heart and muscle contractility, intracellular information transmission and blood coagulation (Kozisek, 2005). Consequently, the outcome of numerous cohort studies recommended that water hardness may protect against many diseases particularly against cardiovascular diseases (Yang et al., 1996), cerebrovascular diseases (Yang et al., 1998), cancer of esophagus (Yang et al., 1999c), cancer of pancreas (Yang et al., 1999d), cancer of rectum (Yang et al. 1999e) and breast cancer (Yang et al., 2000). Drinking water calcium has also proven to be statistically significant in reducing the risk for pre-term birth and low birth weight (Yang et al., 2002). In contrast, Miyake et al. (2004a) suggested that the higher values of hardness can be a risk factor for childhood atopic eczema.

Acidity: Dissolved $\mathrm{CO}_{2}$ is the main factor responsible for acidity in unpolluted waters. $\mathrm{CO}_{2}$ on reaction with water results in the formation of carbonic acid which imparts acidic nature to water. Simultaneously, industrial effluents have a considerable potential to alter the chemistry of groundwater and make it more susceptible to acidification (Carr and Neary 2008). In unsaturated zone, various organic processes like nitrification, base-cation uptake by vegetation, organic acid production in decaying vegetation and oxidation of reduced forms of sulphur influence the groundwater composition, thereby increasing the acidity of percolating water (Reuss et al., 1987). In this study, the minimum value of acidity $(11 \mathrm{mg} / \mathrm{l})$ in groundwater samples was observed at SSB in December whereas the maximum value $(360 \mathrm{mg} / \mathrm{l})$ was recorded at SSA in the month of November. The acidity in the control samples varied from $15.5 \mathrm{mg} / \mathrm{l}$ in October to $87.5 \mathrm{mg} / \mathrm{l}$ in the month of June. The values of acidity in this study were significantly higher $(16.65-63.10 \mathrm{mg} / \mathrm{l})$ than the values reported by Uhegbu et al. (2012) in characterization of groundwater in Aba Metropolis, Nigeria. Elevated acidity levels in groundwater may also mobilize various trace elements e.g., $\mathrm{Cd}, \mathrm{Mn}, \mathrm{Fe}, \mathrm{As}$, and $\mathrm{Hg}$ from soils (Meybeck et al., 1989), thereby making groundwater reserves highly toxic.

Alkalinity: Alkalinity is the potential of water to neutralize a strong acid. The natural sources of alkalinity in groundwater are the geogenic alkalis like $\mathrm{CO}^{2-}$, $\mathrm{HCO}^{3-}$ and $\mathrm{OH}^{-}$salts of $\mathrm{Ca}, \mathrm{Mg}, \mathrm{K}$, and $\mathrm{Na}$. Usually, natural water has alkalinity ranging from 10 to 500 $\mathrm{mg} / \mathrm{L}$. This feature is important while determining the suitability of water for irrigation purposes. In this study, the minimum value of alkalinity $(302.5 \mathrm{mg} / \mathrm{l})$ in groundwater was observed at SSC in March whereas alkalinity was maximum $(525.0 \mathrm{mg} / \mathrm{l})$ at SSD in the month of October. Alkalinity in control samples of groundwater ranged between $250.67 \mathrm{mg} / \mathrm{l}$ in February and $550.77 \mathrm{mg} / \mathrm{l}$ in October. Yadav et al. (2012) reported relatively lower values for alkalinity (160-610) in ground water of Bhiwadi industrial area at Alwar, India. The interaction of vadose water with soil and bedrock results in ion-exchange process that reduces groundwater acidity (Dahmke et al., 1986 and Moss and Edmunds 1992). Water with low alkalinity may be corrosive and can irritate the eyes. In contrast, higher alkalinity in water causes soda-like taste and can dry out the skin due to basic $\mathrm{pH}$. Excessive alkalinity also causes scaling in plumbing and distribution systems thereby reducing their water supply efficiency.

Potassium: The K occurs naturally in most of the minerals. It gets dissolved in soil solution through weathering phenomenon. This dissolved phase serves as a main source of groundwater $\mathrm{K}$ through downward seepage (Lenntech 2014b). In present study, the K was observed to be minimum $(0.13 \mathrm{mg} / \mathrm{l})$ at $\mathrm{SSC}$ in September, whereas the maximum value $(2.30 \mathrm{mg} / \mathrm{l})$ was recorded at SSD in the month of March. The $\mathrm{K}$ in control samples was below the detection level in March and April whereas it ranged up to the maximum value of $1.34 \mathrm{mg} / \mathrm{l}$ in the month of May. The present observations were extremely lower (6-102 mg/l) than that reported by Gadhave et al. (2008) in groundwater of an industrial area at Shrirampur, India. $\mathrm{K}$ is a vital trace element in living organism including humans. In reference to physiology, vital role of $\mathrm{K}$ includes its function in nerve stimulus, muscle contraction, blood pressure regulation and protein dissolution. Higher $\mathrm{K}$ levels in drinking water could be a major concern for human health but there are no reports illustrating any harmful impact of the same. Thus, any health-based guideline value for $\mathrm{K}$ in drinking water is not established yet. Still, K may cause some health consequences in susceptible individuals (individuals with renal and cardiovascular diseases) resulting from $\mathrm{K}$ intake from drinking water that is well below the level at which adverse health effects may occur. Infants also have a limited renal reserve and immature kidney function and may therefore be more vulnerable (WHO 2009).

Phosphorus: Generally, phosphates $\left(\mathrm{PO}_{4}\right)$ are the most common form of phosphorus $(\mathrm{P})$ that frequently occurs in natural water (APHA 2012). $P$ in groundwater may be due to various natural factors like leaching from rocks and soil media and runoff from fertilizer applications. Soils have a small capacity to retain $\mathrm{P}$ and once the ability of soil to absorb more P exceeds, the excess gets dissolved in soil solution and ultimately gets percolated to the aquifer (Domagalski and Johnson, 2012). This factor is a significant source of $\mathrm{P}$ contamination in groundwater. In this study, the concentration of $\mathrm{P}$ was nil at almost all sampling sites 
Tushar Arora et al. / J. Appl. \& Nat. Sci. 6 (2): 825 - 843 (2014)
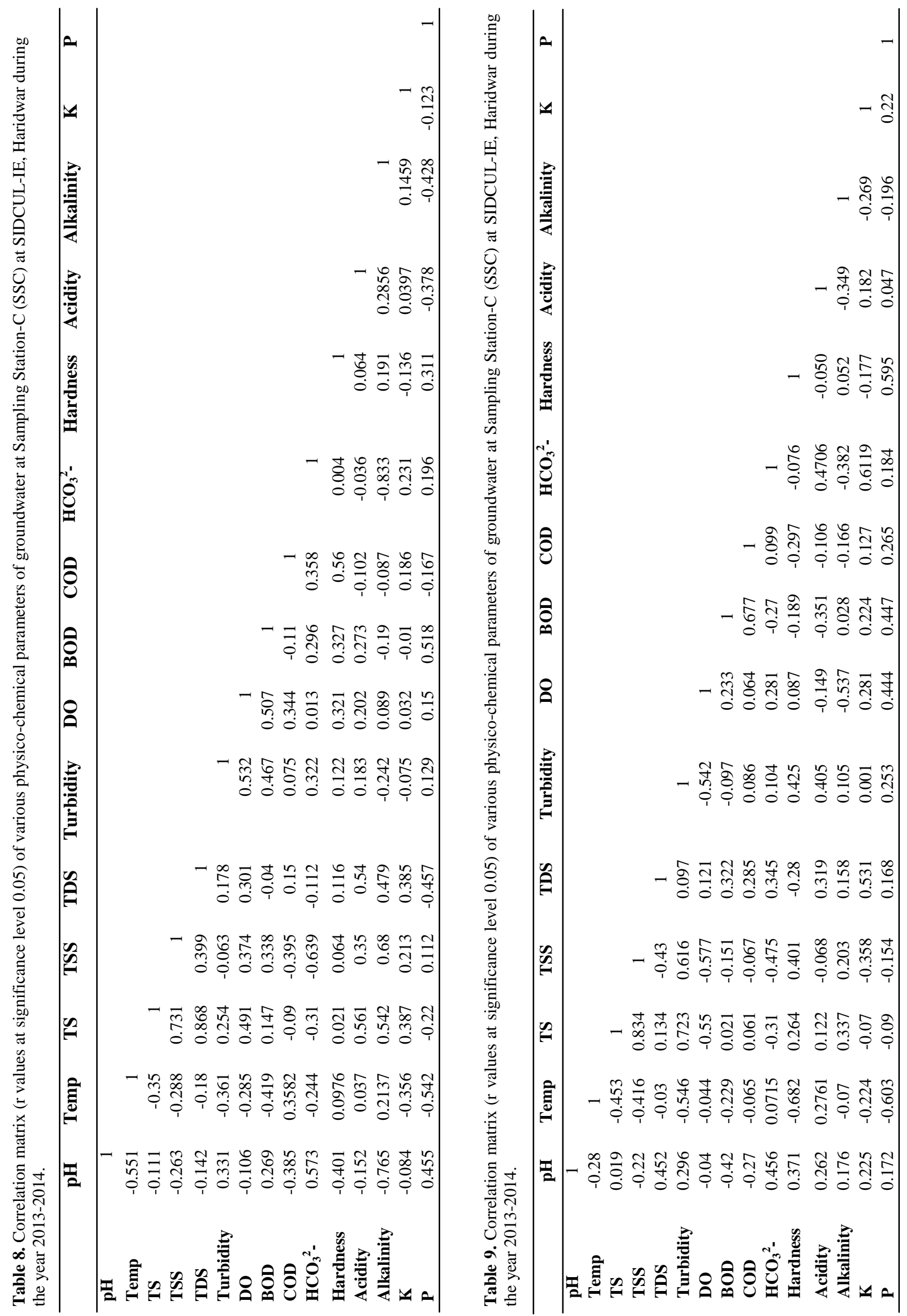


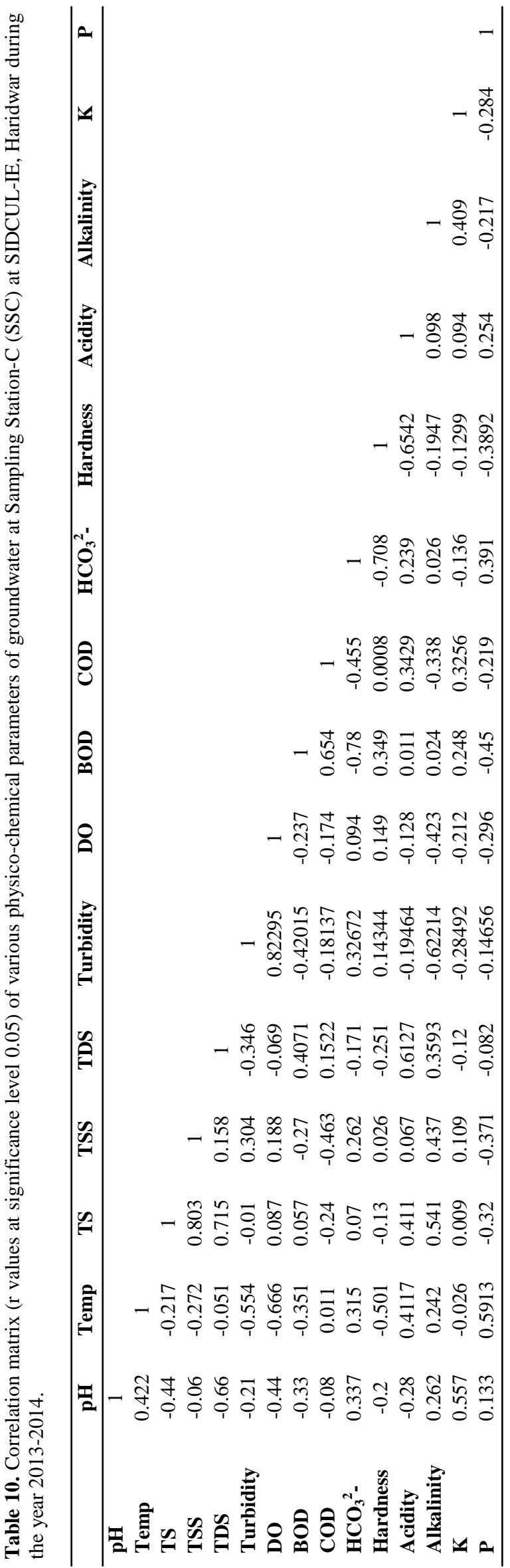

over and over again while the maximum value of $\mathrm{P}$ $(0.26 \mathrm{mg} / \mathrm{l})$ was observed at SSD in the month of February. Similarly, the values for $\mathrm{P}$ were nil at control sites all the time while the highest concentration for control samples was recorded $0.2 \mathrm{mg} / \mathrm{l}$ in April. Relatively higher concentration of $\mathrm{P}$ at control sites pretend to be of geogenic origin. These values were significantly higher $(0.01-0.09 \mathrm{mg} / \mathrm{l})$ than the values reported by Khanam and Singh (2014) in groundwater samples at U. S. Nagar, India. Biologically, the $\mathrm{PO}_{4}$ are one of the basic components of DNA materials that have a vital role in energy distribution process. Excess of $\mathrm{PO}_{4}$ may cause health problems such as kidney damage and osteoporosis. Hyperphosphatemia is a late -stage chronic kidney disease that may be caused due to elevated levels of $\mathrm{PO}_{4}$ in blood, thereby resulting in the increased cardiovascular morbidity and mortality in effected individuals (Lee and Marks 2014).This disease is often caused due to excess of $\mathrm{PO}_{4}$ (as food additives) in food but there is no literature suggesting any water-borne disease resulting due to high $\mathrm{P}$ concentration in drinking water.

Correlation among physico-chemical parameters at different sampling stations of SIDCUL-IE: Karl Pearson Correlation matrix calculated at significant level $(0.05)$ for the water quality parameters is shown in Tables 6 to Table 10. Various parameters showed moderate to significant positive correlation with one another. The parameters like TS-TSS $(r=0.963)$, TSS -turbidity $(\mathrm{r}=0.412)$ at SSA (Table 6), TS-turbidity $(\mathrm{r}=0.406)$ at SSB (Table 7) and TSS-turbidity $(\mathrm{r}=0.616)$ at SSD (Table 8) were significantly and positively inter-related with each other which may be due to the presence of higher percentage of suspended particulate matter. Higher phosphates and turbidity (particulates) stimulates and promotes the microbial growth in drinking water (Miettinen et al., 1997), thereby leading to increased values of BOD and COD. This statement also justifies the observed positive correlation of turbidity-DO ( $\mathrm{r}=0.262$, insignificant $)$ COD -phosphorus ( $\mathrm{r}=0.629$, significant), at SSA (Table 6) and turbidity-BOD ( $\mathrm{r}=0.467$, moderately significant), BOD-phosphorus ( $\mathrm{r}=0.518$, moderately significant) at SSC (Table 8). The possible reason may also be the calcium ions (hardness causing chemical species) which provide an environment conducive to growth of micro-organisms (Anonymous, 1999), thereby resulting in higher values of BOD. Also, at SSA (Table 6) and SSC (Table 8), turbidity-phosphorus were observed to have an insignificant positive correlation i.e. $(\mathrm{r}=0.152)$ and $(r=0.129)$ respectively. This may be due to the reason that the suspended particles may be probably of organic-phosphate origin. A similar insignificant positive relationship was observed between TSS-phosphorus $(\mathrm{r}=0.112)$ at SSC (Table 8). At SSD and Control site, BOD-COD ( $\mathrm{r}=$ 0.6771) (Table 9) and ( $\mathrm{r}=0.654)$ (Table 10) were observed to have a significant positive correlation. A similar trend of significant positive 
correlation of BOD-COD in groundwater at Perur, India has also been observed by Usharani et al. (2010). Similarly, at SSA and SSB pH and bicarbonate were observed to have positively insignificant $(r=0.375)$ (Table 6) and significant $(\mathrm{r}=0.668)$ (Table 7) relation respectively. This may probably be due to the fact that bicarbonate ions bear an alkaline character and thereby causing a rise in the $\mathrm{pH}$ level of water.

However, the observed values of temperature showed poor to significant negative correlation with $\mathrm{pH}$ and BOD at different sampling stations like temperature-DO $(\mathrm{r}=-0.477)$ at SSA (Table 6), pH-temperature $(\mathrm{r}=-0.27)$ at SSB (Table 7), $\mathrm{pH}$-temperature $(\mathrm{r}=-0.551)$ at SSC (Table 8) and pH-temperature $(\mathrm{r}=-0.28)$ at SSD (Table 9) and temperature-DO $(\mathrm{r}=-0.666)$ at control site (Table 10). This may possibly due to the fact that the values of $\mathrm{pH}$ and DO had characteristic thermal sensitivity (Carr and Neary, 2008). At SSC, bicarbonateacidity ( $\mathrm{r}=-0.833$ ) (Table 8 ) and at Control site, hardness-acidity $\quad(\mathrm{r}=-0.6542) \quad$ (Table 10) were observed to have a significant negative correlation which may be likely due to the reason that acidity and alkalinity have an inverse relationship as bicarbonates ions are the major contributor of alkalinity as well as of hardness (Wilson, 2011).

\section{Conclusion}

The industrial establishments at SIDCUL-IE are recent and the region has considerably deeper water table depths, therefore the ground water reserves at this IE are under preliminary phase of influence of surface activities. The higher assimilation capacity of pedogenic formations may possibly retain some contaminants thereof. However, the groundwater at SSD was observed to be of comparatively impaired quality with elevated levels of TS, TSS, turbidity, bicarbonates and alkalinity, while SSA and SSB had higher organic load. The coefficient of correlation (r) values showed variations among different physicochemical parameters at different sampling stations of SIDCUL-IE. The parameters like TS-TSS, TSSturbidity at SSA, TS-turbidity at SSB and TSSturbidity at SSD were significantly and positively inter -related with each other which may be due to the presence of higher percentage of suspended particulate matter. The increased values of BOD and COD may be due to the fact that higher phosphates, turbidity (particulates) and calcium ions (hardness causing chemical species) might stimulate and promote the microbial growth in drinking water, thereby leading to increased values of BOD and COD. Also, at SSA and SSC, turbidity-phosphorus were observed to have an insignificant positive correlation which may be due to the reason that the suspended particles may be probably of organic-phosphate origin. At SSA and SSB stations, $\mathrm{pH}$ and bicarbonates were observed to have positively insignificant and significant relation respectively. This may possibly be due to the reason that bicarbonate ions have an alkaline character and thereby causing a rise in the $\mathrm{pH}$ level of water.

In addition, the groundwater samples at SSC were oxygen-deficient with quite higher amount of dissolved solids. The control groundwater samples had relatively higher hardness and phosphorus values which may possibly be of geogenic in nature. The present characteristic quality of groundwater indicated that the general public and industrial workers may rationally use groundwater for potable use. However, on persistence of indiscriminate disposal of industrial effluents and sludges on fallow terrains and open drainage channels, the groundwater contamination may gradually build up at regional scale over a period of 5-10 years. The contaminated water in supplies may result in synergistic reactions in public distribution system. Further, it may significantly pose serious threats among the local population in and around the SIDCUL-IE and Shivalik Nagar. Moreover, it is recommended that concerned agencies should carry out periodic monitoring of groundwater quality at SIDCUL-IE. At the same time, regular assessment of waste treatment and disposal system must also be taken care to ensure compliance of the regulatory guidelines.

\section{ACKNOWLEDGEMENT}

The authors acknowledge Department of Science and Technology, Government of India for sanctioning the research project (File no: DST/TM/WTI/2K12/34) and financial assistance for the reported research.

\section{REFERENCES}

Abbulu, Y. and Rao, G.V.R.S. (2013). A study on physico-chemical characteristics of groundwater in the industrial zone of Visakhapatnam, Andhra Pradesh, AJER, 2(10): 112-116.

Ahmed, M.J., Haque, M.R., Ahsan, A., Siraj, S., Bhuiyan, M.H.R., Bhattacharjee, S.C. and Islam, S. (2010). Physicochemical assessment of surface and ground water quality of the Greater Chittagong region of Bangladesh. Pak J Anal Environ Chem., 11(2):1-11.

Al-Adamat, R.A.N, Foster, I,D.L., and Baban, S.M.J, (2003). Groundwater vulnerability and risk mapping for the Basaltic aquifer of the Azraq basin of Jordan using GIS, Remote sensing and DRASTIC. Appl Geogr., 23:303-324.

Alley, W.M. (2007). The importance of monitoring to groundwater management. In: Holliday L et al. (ed) Strengthening science-based decision making in developing countries. The National Academies Press, Washington DC, pp 76-85.

Anonymous (1999). Understanding dilution and seeding procedures in BOD test. Hydrology Project Training Module., Pp 33.

APHA (2012). Standard methods of water and wastewater analysis 22th edn. American Public Health Association, Washington DC.

Ashbolt, N.J. (2004). Microbial contamination of drinking water and disease outcomes in developing regions. 
Toxicol., 198: 229-238.

Aulakh, M.S., Khurana, M.P.S. and Singh, D. (2009). Water pollution related to agricultural, industrial, and urban activities, and its effects on the food chain: Case studies from Punjab. Journal of New Seeds, 10:112-137.

BIS (1991). Bureau of Indian Standards; Indian standards: Drinking water specifications IS: 10500.

Barrett, K.E., Barman, S.M., Brooks, H.L. and Boitano, S. (2010). Ganong's review of medical physiology, The McGraw-Hill Companies, Ontario.

Bhadra, B.K., Pathak, S. and Sharma, J.R. (2013). Impact of industrial effluents on groundwater around Pali city, Rajasthan using field and satellite data. J. Geol. Soc India, 82:675-691.

Bhaskar, C.V., Kumar, K. and Nagendrappa, G. (2010). Assessment of heavy metals in water samples of certain locations situated around Tumkur, Karnataka, India. EJournal of Chemistry, 7(2):349-352.

Bingbing, X., Qiujin, X., Cunzhen, L., Li, L. and Lijia, J. (2014). Occurrence and health risk assessment of trace heavy metals via groundwater in Shizhuyuan Polymetallic mine in Chenzhou City, China. Front. Environ. Sc.i Eng., doi: 10.1007/s11783-014-0675-8.

Brindha, K., and Elango, L. (2012). Impact of tanning ndustries on groundwater quality near a metropolitan city in India. Water Resour. Manag., 26(6):1747-1761.

Brindha, K., Vaman, K.V.N, Srinivasan, K., Babu, M.S., and Elango, L. (2014). Identification of surface water -groundwater interaction by hydro-geochemical indicators and assessing its suitability for drinking and irrigational purposes in Chennai, Southern India. Appl Water Sci .,4:159-174.

Bryant, E.A., Fulton, G.P., Budd, G.C., and Sawyer, H. (1992). Disinfection alternatives for safe drinking water. Van Nostrand Reinhold, New York.

Burton, A.C., and Cornhill, J.F. (1977) Correlation of cancer death rates with altitude and with the quality of water supply of the 100 largest cities in the United States. $J$. Toxicol Env. Health, 3:465-478.

Carr, G.M., and Neary, J.P. (2008) Water quality for ecosystem and human health, 2nd edn. United Nations Environment Programme: Global Environment Monitoring System. Accessed 26 September 2014.

CGWB (2009). Groundwater brochure of Hardwar District, Uttarakhand. Central Ground Water Board, Dehradun, Uttaranchal Region, India. http://cgwb.gov.in/ District_Profile/Uttarakhand/ Hardwar.pdf Accessed 25 September 2014

Chow, A.T., Dahlgren, R.A., Zhang, Q., and Wong, P.K. (2008). Relationships between specific ultraviolet absorbance and trihalomethane precursors of different carbon sources. J. Water Supply Res. T., 57: 471-480.

Coen, G., Sardella, D., Barbera, G., Ferrannini, M., Comegna, C., Ferazzoli, F., Dinnella, A., D’Anello, E. and Simeoni, P. (2001). Urinary composition and lithogenic risk in normal subjects following oligomineral versus bicarbonate-alkaline high calcium mineral water intake. Urologia Internationalis, 67:49-53.

Craun, G.F., and McCabe, L.J. (1975) Problems associated with metals in drinking water. $J$ Am Water Works Ass., 67:593-599.

Dahmke, A., Matthess, G., Pekdeger, A., Schenk, D. and Schulz, H.D. (1986). Near-surface geochemical processes in quaternary sediments. J. Geol. Soc., 143:667-672.
Dimitriou, E., Karaouzas, I., Sarantakos, K., Zacharias, I., Bogdanos, K. and Diapoulis, A. (2008). Groundwater risk assessment at a heavily industrialized catchment and the associated impacts on a peri-urban wetland. $J$. Environ. Manage., 88(3):526-553.

Domagalski, J.L. and Johnson, H. (2012). Phosphorus and Groundwater: Establishing links between agricultural use and transport to streams: U.S. Geological Survey Fact Sheet 2012-3004. http://pubs.usgs.gov/ fs/2012/3004/pdf/fs20123004.pdf. Accessed 30th September 2014.

Fazila, M.I., Iqbalb, M.A., and Abdullaha, S. (2012). Study on Heavy Metal Ion Contamination of Groundwater Reserves in Beed City, Maharashtra, India. Bull. Environ. Pharmacol. Life Sci., 1 (8), 18- 21.

Gadhave, A.G., Thorat, D.G. and Uphade, B.K. (2008). Water quality parameters of ground water near industrial areas, Shrirampur (M.S). Rasayan J. Chem, 1 (4), 853-855

Hanson, M.L. and Solomon, K.R. (2004). Haloacetic acids in the aquatic environment. Part I: macrophyte toxicity. Environ. Pollut., 130: 371-383.

Health Canada. (1991). Environmental workplace health: Total Dissolved Solids. www.hc-sc.gc.ca/ewh-semt/ alt_formats/hecs-sesc/pdf/pubs/water-eau/tds-mdt/tds -mdt-eng.pdf. Accessed 26th September 2014

Health Canada. (1995). Environmental and workplace health: Temperature. Retrieved from http://www.hc-sc.gc.ca/ ewh-semt/alt_formats/hecs-sesc/pdf/pubs/water-eau/ temperature /temp erature - eng.pdf. Accessed 20th August 2014.

Jain, P.C. and Jain, M. (1990). Engineering Chemistry. 13th edn, Dhanpat Rai Publishing Company, New Delhi.

Jung, C.W. and Son, H.J. (2008). The relationship between disinfection by-products formation and characteristics of natural organic matter in raw water. Korean Journal of Chemical Engineering, 25:714-720.

Karunakaran, K., Thamilarasu, P. and Sharmila, R. (2009). Statistical study on physicochemical characteristics of groundwater in and around Namakka, Tamilnadu, India. E- Journal of Chemistry, 6(3):909-914.

Khanam, Z., Singh, V. (2014). Groundwater quality assessment near polluted canal area in Kichha town, Uttarakhand, India. International Journal of Recent Scientific Research, 5(2):362-368.

Kozisek, F. (2005). Health risks from drinking demineralised water: Nutrients in drinking water. World Health Organization, Geneva.

Krasner, K.S. (2009). The formation and control of emerging disinfection by-products of health concern. Phil Trans $R$ Soc A, 367:4077-4095.

Kumar, C.P. (2012). Climate change and its impact on groundwater resources. Int. J. Engg. Sci., 1(5):43-60.

Kumar, D.S., Kumar, P.S. and Gopalakrishnan, P. (2011). Ground water quality assessment in paper mill effluent irrigated area-using multivariate statistical analysis. World Appl Sci J., 13(4):829-836.

Lee, G.J. and Marks, J. (2014). Intestinal phosphate transport: a therapeutic target in chronic kidney disease and beyond ? Pediatr Nephrol., doi:10.1007/s00467-014 $-2759-x$.

Lenntech (2014a). Oxygen (O) and water. Water Treatment. Lenntech, Rotterdamseweg, Netherlands (Lenntech Water Treatment and Air Purification). http:// www.lenntech.com/ periodic/ water/oxygen/oxygen-and 
-water.htm. Accessed on 1st October 2014.

Lenntech (2014b). Potassium (K) and water. Water treatment. Lenntech, Rotterdamseweg, Netherlands (Lenntech Water Treatment and Air Purification). http:// www.lenntech.com/ periodic/water/potassium/ potassium-and-water.htm. Accessed on 1st October 2014.

Leung, C., and Jiao, J.J. (2006) Heavy metal and trace element distributions in groundwater in natural slopes and highly urbanized spaces in Mid-Levels area, Hong Kong. Water Res., 40:753-767

Lutai, G.F. (1992). Chemical composition of drinking water and the health of population. (In Russian) Gig Sanit, $1: 13-15$.

Mann, A.G., Tam, C.C., Higgins, C.D. and Rodrigues, L.C. (2007). The association between drinking water turbidity and gastrointestinal illness: A systematic review. BMC Public Health, 7:256. doi: 10.1186/1471-2458-7-256.

Momba, M.N.B, Tyafa, Z., Makala, N., Brouckaert, .BM. and Obi C.L. (2006). Safe drinking water still a dream in rural areas of South Africa. Case Study: The Eastern Cape Province. Water, SA 32(5):715-720.

Martin, J.A., Ronald, W.B., Ray, C., Steve, E.H. and Pierre, P. (2008). Turbidity and Microbial Risk in Drinking Water. Ministerial Technical Advisory Committee. http://www.health.gov.bc.ca /protect/pdf/ TACsubmitted.pdf. Accessed on 28th September.

Matilainen, A., Vepsalainen, M. and Sillanppa, M. (2010). Natural organic matter removal by coagulation during water treatment: A review. Adv. Colloid Interface Sci.,159:189-197.

Matilainen, A., Gjessing, E.T., Lahtinen, T., Hed, L., Bhatnagar, A. and Sillanpaa, M. (2011). An overview of the methods used in the characterization of natural organic matter in relation to drinking water treatment plant. Chemosphere, 83:1431-1442.

Meybeck, M., Chapman, D.V. and Helmer, R. (1989). Global freshwater quality-A first assessment. Blackwell Reference, Oxford.

Miettinen, I.T., Vartiainen, T., and Martikainen, P.J. (1997) Phosphorus and bacterial growth in drinking water. Appl. Environ. Microbiol., 63, 3242-3245.

Miyake, Y., Yokoyama, T. and Yura, A. (2004a). Ecological association of water hardness with prevalence of childhood atopic dermatitis in a Japanese urban area. Environ Res., 94(1):33-37.

Mondal, N.C., Saxena, V.K. and Singh, V.S. (2005). Assessment of groundwater pollution due to tannery industries in and around Dindigul, Tamilnadu, India. Environ Geol., 48(2):149-157.

Moss, P.D. and Edmunds, W.M. (1992). Processes controlling acid attenuation in the unsaturated zone of a Triassic sandstone aquifer (U.K.), in the absence of carbonate minerals. Appl. Geochem., 7:573-583.

Monarca, S., Donato, F., Zerbini, I., Calderon, R.L. and Craun, G.F. (2006). Review of epidemiological studies on drinking water hardness and cardiovascular diseases. Eur. J. Cardiovasc. Prev. Rehabil., 13:495-506.

Naik, P.K., Dehury, B.N. and Tiwary, A.N. (2007). Ground water pollution around an industrial area in the coastal stretch of Maharastra state, India. Environ. Monit. Assess., 132:207-233.

Nubi, O.A., and Ajuonu, N. (2011). Impacts of industrial effluent and dumpsite leachate discharges on the quality of groundwater in Oyo state, Nigeria. J Geol Soc India
1(3):13-18.

Ntuli, F., Kuipa, P.K. and Muzenda, E. (2011). Designing of sampling programmes for industrial effluent monitoring. Env. Sci. Poll. Res., 18:479-484.

Patel, S., Mohsin, M., Farooqui, M. and Quadri, S.H. (2010). Multivariate analysis of ground water, around sugar factories of Osmanabad District (India). Rasayan $J$. Chem., 3(3):420-424.

Prabha, S., Kumar, M., Kumar, A., Das, P. and Ramanathan, A.L. (2013). Impact assessment of textile effluent on groundwater quality in the vicinity of Tirupur industrial area, southern India. Environmental Earth Sciences, 70(7):3015-3022.

Pujari, P.R. and Deshpande, V.A. (2005) Source apportionment of groundwater pollution around landfill site in Nagpur, India. Environ. Monit. Assess., 111:43-54.

Rajappa, B. (2010). Monitoring of heavy metal concentration in groundwater of Hakinaka Taluk, India. Contemporary Engineering Sciences, 3(4):183-190.

Rajkumar, N., Thirumalaisamy, S., and Lakshumanan, E. (2012). Impact of leachate on groundwater pollution due to non-engineered municipal solid waste landfill sites of erode city, Tamil Nadu, India. Iran J Env Heal Sci Engg, 9(35):1-12.

Rameeza, S., Srikant, V.N.V., Rao, D.M. and Ramakrishna, C. (2012). Study of ground water quality in industrial zone of Visakhapatnam. Adv. Appl. Sci. Res., 3(4):2463-2467.

Ramesh, A., Prakash, B.S.N., Sivapullaiaih, P.V. and Sadhashivaiah, A.S. (2012) Assessment of ground water quality in designated Peenya Industrial Area and Estate, Bangalore, India - A Case Study. IJEP, 2(6):21-25.

Ramesh, K. and Seethe, K. (2013) Hydrochemical Analysis of Surface water and Groundwater in Tannery belt in and around Ranipet, Vellore district, Tamil Nadu, India. Int. J. Res. Chem. Environ., 3(3):36-47.

Rao, V.V.S.G., Dhar, R.L. and Subrahmanyam, K. (2001). Assessment of contaminant migration in groundwater from an industrial development area, Medak District, Andhra Pradesh, India. Water Air Soil Poll., 128 (3-4):369-389.

Ratasuk, C., Kositanont, C. and Ratanatamskul, C. (2008). Removal of haloacetic acids by ozone and biologically active carbon. Sci Asia, 34:293-298.

Reckhow, D.A., Singer, P.C. and Malcolm, R.L. (1990). Chlorination of humic materials: Byproduct formation and chemical interpretations. Environ. Sci. Technol., 24:1655-1664.

Reddy, T., PrasadaRao, P.V.V., Ramana, C.V., Latha, H.S. and Kumar S.B. (2013) Assessment of ground water quality in an industrial agglomeration of Visakhapatnam, A. P. International Journal of Environmental Sciences, 3(5):1383-1389.

Reuss, J.O., Cosby, B.J. and Wright, R.F. (1987). Chemical processes governing soil and water acidification. Nature, 329:27-31.

Rose. S. and Long, A. (1988). Monitoring Dissolved oxygen in ground water: Some basic considerations. Ground. Water. Monit. Rem., 8:93-97.

Ruddick, J.A., Villeneuve, D.C., Chu, I. and Valli, V.E. (1983). A teratological assessment of four trihalomethanes in the rat. J. Environ. Sci. Health B, 18 (3): 333-349.

Sagehashi, M., Shiraishi, K., Fujita, H., Fujii, T. and Sakoda, A. (2005). Ozone decomposition of 2-methylisoborneol (MIB) in adsorption phase on high silica zeolites with 
preventing bromate formation. Water Res., 39:2926-2934.

Saravi. M.M., Keshavarzi, A. and Azareh, A. (2013). Modeling of SAR and sulfate concentration using Artificial Neural Network Approach. Int. J. Agron. Plant Prod., 4(3):499-506.

Sauvant, M.P. and Pepin, D. (2002). Drinking water and cardiovascular disease. Food Chem. Toxicol., 40:1311-1325.

Singh, K.P, Singh, V.K,. Malik, A. and Basant, N. (2006). Distribution of nitrogen species in groundwater aquifers of an industrial area in alluvial Indo-Gangetic Plains-A case study. Environ. Geochem. Health, 28(5):473-485.

Singh, R.P. (2001). Effect of wastewater disposal and extent of industrial pollution in and around Kanpur, Uttar Pradesh, India. Bulletin of Engineering Geology and the Environment, 60(1):31-35.

Sirajudeen, J., Mohidheen, M.K. and Vahith, R.A. (2014). Physico-chemical contamination of groundwater in and around Tirunelveli district, Tamil Nadu. Advances in Applied Science Research, 5(2):49-54.

Schroeder, H.A. (1960). Relation between mortality from cardiovascular disease and treated water supplies. J. Am. Med. Assoc., 172:1902-1908.

Sekhon, G.S. and Singh, B. (2013). Estimation of heavy metals in the groundwater of Patiala district of Punjab, India. $E R, 1(1): 1-4$.

Subbarao, N., Rao, V.V.S.G. and Gupta, C.P. (1998). Groundwater pollution due to discharge of industrial effluents in Venkatapuram area, Visakhapatnam, Andhra Pradesh, India. Environ. Geol., 33(4):289-294.

Uhegbu, A., Chukwnenyoke, Igboekwe and Uzoma, M. (2012). Characterization and Quality Assessment of Groundwater in parts of Aba Metropolis Southern Nigeria. Arch. Appl. Sci. Res., 4(5):1949-1957.

Ullah, R., Malik, R.N. and Qadir, A. (2009). Assessment of groundwater contamination in an industrial city, Sialkot, Pakistan. AJEST, 3(12):429-446.

Usharani, K., Umarani, K., Ayyasamy, P.M., Shanthi, K. and Lakshmanaperumalsamy, P. (2010). Physico-Chemical and Bacteriological Characteristics of Noyyal River and Ground Water Quality of Perur, India. J. Appl. Sci. Environ. Manage., 14(2): 29-35.

Venkateswarlu, G. (2014). Analytical study on effects of water quality parameters using remote sensing and GIS under Hyderabad urban area zone-V. Int. J. Res. Engg. Tech., 3(3):308-316.

Watson. P.S. and Davies, S. (2011). Modeling the effects of population growth on water resources: A CGE analysis of the South Platte River Basin in Colorado. Ann. Reg. Sci., 46(2):331-348.

White, D.M., Garland, D.S., Narr, J. and Woolard, C.R. (2003). Natural organic matter and DBP formation potential in Alaskan water supplies. Water Res., 37:939-947.

WHO (1986). World Health Organization Working Group. Health impact of acidic deposition. Sci. Tot. Environ., 52:157-187.

WHO (2003). Total dissolved solids in drinking water: Background document for preparation of WHO Guidelines for drinking -water quality. World Health Organization, Geneva.
WHO (2007). Total dissolved solids in drinking water: Guidelines for Drinking Water Quality World Health Organization, Geneva.

WHO (2008). Guidelines for drinking-water quality. Third edition. World Health Organization, Geneva.

WHO (2009). Potassium in drinking-water: Background document for development of WHO Guidelines for Drinking-water Quality. World Health Organization, Geneva.

WHO (2011). Guidelines for drinking-water quality. Fourth edition. World Health Organization, Geneva.

Wilson, C.P. (2011). Water Quality Notes: Alkalinity and Hardness. University of Florida.

Wong, H., Mok, K.M. and Fan, X.J. (2007). Natural organic matter and formation of trihalomethanes in two water treatment processes. Desalination, 210(1-3): 44-51.

Wu, B., Zhao, D., Zhang, Y., Zhang, X. and Cheng S. (2009). Multivariate statistical study of organic pollutants in Nanjing reaches of Yangtze River. J. Hazard. Mater., 169:1093-1098.

Yadav, R.N., Dagar, N.K., Yadav, R. and Gupta, P. (2012). Variability in physico-chemical parameters of ground water of north-east zone of the Bhiwadi industrial area (Alwar). J. Curr. Chem. Pharm. Sc., 2(3):198-208.

Yang, Ch.Y., Chiu, J.F., Chiu, H.F., Wang, T.N., Lee, Ch. H. and Ko, Y.Ch. (1996). Relationship between water hardness and coronary mortality in Taiwan. J. Toxicol. Environ. Health., 49:1-9.

Yang, Ch.Y. (1998). Calcium and magnesium in drinking water and risk of death from cerebrovascular disease. Stroke, 29:411-414.

Yang, Ch.Y, Chiu, H.F., Cheng, M.F., Tsai, S.S., Hung, Ch.F. and Lin, M.Ch. (1999c). Esophageal cancer mortality and total hardness levels in Taiwan's drinking water. Environ. Research, 81:302-308.

Yang, Ch.Y., Chiu, H.F., Cheng, M.F., Tsai, S.S., Hung, Ch. F. and Tseng, Y.T. (1999d) Pancreatic cancer mortality and total hardness levels in Taiwan's drinking water. J. Toxicol. Environ. Health A, 56:361-369.

Yang, Ch.Y., Tsai, S.S., Lai, T.Ch., Hung, Ch.F., and Chiu H.F. (1999e). Rectal cancer mortality and total hardness levels in Taiwan's drinking water. Environ. Res. A, 80:311-316.

Yang, Ch.Y., Chiu, H.F., Cheng, M.F., Hsu, T.Y., Cheng, M.F. and $\mathrm{Wu}$, T.N. (2000). Calcium and magnesium in drinking water and the risk of death from breast cancer. J. Toxicol. Environ. Health A, 60:231-241.

Yang, Ch.Y., Chiu, H.F., Chang, Ch.Ch., Wu, T.N. and Sung, F.Ch. (2002). Association of very low birth weight with calcium levels in drinking water. Environ. Research A, 89:189-194.

Zhou, R., Hu, Z., Yang, K. and Chen, Y. (2006). Distribution of organochlorine pesticides in surface water and sediments from Qiantang River, East China. J. Hazard Mater., 137:68-75.

Zoeteman, B.C.J. (1980). Sensory Assessment of Water Quality. Oxford-New York-Toronto-Sydney-Paris -Frankfurt, Pergamon-Press. 